Gustavo Toro

Magíster en Administración de Empresas de la Universidad de los Andes. Magíster en Economía de la Universidad Javeriana. Presidente ejecutivo de la Asociación Hotelera y Turística de Colombia - Cotelco

Bogotá - Colombia

[gustavo.toro@uexternado.edu.co]

María Luisa Galán Máster en Gestión de destinos turísticos locales y regionales de la Universidad de Barcelona, España Docente investigadora de la Facultad de Administración de Empresas Turísticas y Hoteleras de la Universidad Externado de Colombia.

Bogotá - Colombia

[maria.galan@uexternado.edu.co]

Luis Alejandro Pico

Economista de la Universidad Nacional de Colombia. Docente investigador en la Fundación Universitaria Cafam (Colombia) Escuela de Turismo y Gastronomía.

Bogotá - Colombia

Edna Rozo

Doctoranda en Estudios Sociales de la Universidad Externado de Colombia.

Directora Maestría en Planificación y Gestión del Turismo y coordinadora de investigaciones Facultad de Administración de Empresas Turísticas y Hoteleras. Universidad Externado de Colombia. Bogotá - Colombia [edna.rozo@uexternado.edu.co]

Hayda Suescún

Administradora de Empresas Turística de la Escuela Colombiana de Hotelería y Turismo ECOTET. Directora General. S7ete Turismo Estratégico.

Bogotá- Colombia.

[hayda@7turismoestrategico.com]

\section{LA PLANIFICACIÓN TURÍSTICA DESDE EL ENFOQUE DE LA COMPETITIVIDAD: CASO COLOMBIA $^{1}$}

1 Cabe destacar que el análisis realizado por los autores, proviene de los datos (cuantitativos y cualitativos) extraídos de los informes de los once planes, es decir, de la Unión Temporal de Turismo (UTT) conformada por las citadas entidades en 2012.

Fecha de recepción: 5 de agosto de 2014

Fecha de modificación: 8 de octubre de 2014

Fecha de aceptación: 22 de enero de 2015

Para citar el artículo: Toro, G, Galán, M., Pico, L., Rozo, E. y Suescún, H. (2015). La planificación turística desde el enfoque de la competitividad: caso Colombia, Turismo y Sociedad, XVI pp. 131-185 DOI: http://dx.doi.org/10.18601/01207555.n16.09
TOURISM PLANNING FROM THEAPPROACH TO COMPETITIVENESS: COLOMBIA

CASE STUDY

\section{Resumen}

Este documento de investigación tiene el objetivo de mostrar, de una manera global, los principales resultados que derivan de la formulación de once planes de desarrollo turístico ${ }^{2}$ realizados en Colombia en 2012. Así las cosas, se pretende que el lector tenga una visión panorámica de la planificación turística en Colombia. El artículo describe el enfoque metodológico del proceso adelantado, el cual se fundamenta en algunos de los factores planteados por los teóricos canadienses Crouch y Ritchie, a saber: atracción, soporte, producción y gestión de destino. Posteriormente se muestran las tendencias generales, derivadas del análisis de dichos factores, que expresan la realidad turística del país, y a partir de las cuales se establecen los resultados, conclusiones y acciones por seguir.

2 El equipo de trabajo interdisciplinario está conformado por los autores del presente artículo y los siguientes consultores: Martha Cruz Betancourt, Francisco Ciri, Lorena Waserman, Sandra Karime Zabala Corredor, Paola Mercado, Lina Silva, Paola Villalobos, Ana María Rocha, Carlos Urrego, Rossalyn Hoyos, Josefina Klinger, Carlos Alberto Palacio Londoño, Ángela María Jiménez Avilés, Ronald Penagos, Yefferson Camilo Monsalve, Paola Mercado, Orieta Barrios, Carolina Vanderhuck Arias, Paola Marrugo, Irene Torres, Fausto Sáenz, Adriana Rodríguez Morales, Mauricio Jaramillo, María Luisa López Alzate, Ángela Claro, Cristina Beltrán, Luisa Fernanda Osorio, María Cristina Ríos, Sindy Melissa Fuentes Pulido, Alexander Beltrán, José Mario Mayorga Henao, Fabián Díaz, Christiam Ruiz Benítez, William Gerley Pinilla Ríos, María Eugenia Giraldo Rodríguez, Diva Marcela García García, Ana Milena Landazábal, Migdalia Rojas, William Baquero, Leonardo Sansón, Francisco Lagos, Julia Edith Paredes, Ana Lucía España Delgado, Janeth López, Mauricio Aranha Villas, Yuly Gretel Leal, Alex Buitrago, Fernando Delgado, Juan Pablo Díaz, Diana Carolina Villegas Casanova, Jorge Bonilla, Gustavo Adolfo Jiménez, Celmira Pereira, Hélber Bermúdez, Luis Carlos Sierra, Camilo Andrés Valbuena, Juan Assmus, José María Hoyos, Víctor Cuervo, Fernando Penagos Zapata, Alejandra Orozco y Héctor Fabio Trujillo. Por otro lado, se agradece el constante apoyo y liderazgo de los funcionarios de las gobernaciones y alcaldías que participaron en el proceso, sin los cuales no hubiera sido posible la elaboración de los planes de desarrollo turístico. 
Palabras clave: Factores de competitividad, planificación, destino, clúster, microclúster.

\begin{abstract}
This research paper has the objective to show in a comprehensive way, the results that were thrown by the eleven tourism development plans made in Colombia, in 2012. In fact, it is intended to give an overview of tourism planning in the country. Originally, the article presents the methodological approach of the process, which is based on the four competitiveness factors formulated by canadian academics Crouch and Ritchie: attraction, support, production and destination management. Subsequently, the authors show the general trends (national trends) in the four factors analyzed, to have a view of the whole situation: weaknesses, opportunities, strengths and threats and thus, draw the results and the conclusions under the advanced process.
\end{abstract}

Keywords: Competitiveness factors, planning, destination, clúster, microcluster.

\section{Introducción}

Sin duda, la planificación turística es la piedra angular del desarrollo sostenible del turismo. No es posible pensar en un turismo respetuoso del medio ambiente, de la cultura y que genere beneficios económicos a los inversionistas y a las comunidades si este no se desarrolla de manera planificada.

Colombia es un ejemplo de nación que ha venido propiciando procesos de planificación turística en la mayoría de sus regiones desde 1994. Además de contar con ventajas comparativas importantes, se considera referente mundial en la construcción y la generación de una imagen positiva y de mayor confianza en los focos emisores de turistas internacionales. A pesar de lo anterior, el país se ha caracterizado por un desarrollo turístico espontáneo y poco competitivo, sobre todo en el ámbito regional, donde se presentan conflictos importantes, como la existencia de comunidades aisladas y poco beneficiadas por el turismo y la proliferación de empresas poco competitivas en términos de su inserción en un mundo cada vez más globalizado.

En 2011, el Ministerio de Comercio, Industria y Turismo y el Fondo de Promoción Turística decidieron contratar la elaboración de los planes de desarrollo turístico de 18 departamentos colombianos, para lo cual abrieron seis licitaciones públicas, de las cuales, cuatro fueron ganadas por igual número de uniones temporales de turismo, conformadas por la Fundación Universitaria Cafam y la empresa de consultoría Tourism Consulting S. A. S Estas licitaciones comprendían doce departamentos, de los cuales finalmente se excluyó a Chocó, quedando once en total: Cundinamarca, Santander, Bolívar, Norte de Santander, Guajira, Caldas, Antioquia, Huila, Tolima, Valle del Cauca y Nariño.

\section{Marco teórico}

La planificación y el desarrollo turístico de los destinos deben ser abordados desde una perspectiva integral, teniendo en cuenta los múltiples factores que intervienen y, en especial, el papel que cada una de las partes interesadas desempeña en la configuración de un sector que cada día toma mayor relevancia en el desarrollo económico de las regiones, especialmente en aquellos países con altas potencialidades turísticas que han encontrado en él un motor para impulsar sus economías, permitiendo la generación de ingresos, el avance de las comunidades locales $\mathrm{y}$, por ende, el mejoramiento de la calidad de vida de la población.

Según la Organización Mundial del Turismo (en adelante OMT), el turismo internacional representa el $29 \%$ del total de las exportaciones mundiales de servicios y el $6 \%$ de las 
exportaciones globales de bienes y servicios, ocupando el quinto puesto, después de sectores tradicionales como los combustibles, los productos químicos y alimenticios, y los productos de automoción, mientras que para algunos países en desarrollo el turismo corresponde a la actividad que mayores exportaciones genera, convirtiéndose en un importante factor de desarrollo local (2014).

De hecho, a partir de 1996, con base en la agenda del Earth Council, la Organización de Naciones Unidas promueve el turismo como un instrumento de participación y de involucramiento de la comunidad y sus miembros en proyectos de desarrollo local, lo cual transciende a nivel estratégico a partir de la adopción de los Objetivos de Desarrollo del Milenio, en los que se enfatiza en la erradicación de la pobreza extrema y el hambre, mostrando el turismo como un mecanismo eficiente y viable que permite mitigar los efectos del flagelo de la pobreza (Jiménez y Cavazos, 2012).

Considerando lo anteriormente expuesto, no puede obviarse o tener a menos el análisis de un sector conformado por una industria estructurada en una cadena de valor que revierte beneficios a las comunidades que están inmersas en el proceso productivo de aquellos bienes y servicios que el consumidor final, el turista, adquiere. Dicha cadena de valor puede ser entendida como una red compleja de interacciones entre diferentes actores que en la mayoría de los casos termina siendo invisible para el turista. Por consiguiente, los efectos que el turismo genera sobre la economía serán variados y de considerable incidencia, teniendo en cuenta el gran número de involucrados, además de los sectores económicos que forman parte de la cadena de suministros de la industria turística.

En este orden de ideas, algunos autores han desarrollado investigaciones que buscan cuantificar los efectos directos e indirectos que la actividad turística produce en una economía, especialmente en temas de generación de valor y de ingresos. En esta línea, Klytchnikova y Dorosh (2013) muestran la importancia de la medición de las incidencias del sector turismo, con el fin de determinar las relaciones existentes entre este y los demás sectores de la economía, de tal manera que a partir del cálculo de los multiplicadores, se hace visible la influencia sobre la generación de ingresos, salarios y el valor agregado en todas las actividades relacionadas ${ }^{3}$.

Por lo antes expuesto, y dada su naturaleza sui géneris, el análisis del sector turismo debe ser abordado desde una perspectiva multidisciplinaria, involucrando elementos de diferentes ramas de la ciencia para comprender sus diversas interacciones, promover resultados favorables para su continuo desarrollo e impulsar la sostenibilidad de dicha actividad por medio de la preservación de sus recursos.

Una de las aristas con mayor incidencia en el análisis del sector turismo tiene que ver con la demanda, la cual ha mostrado constantes e importantes cambios en sus determinantes en los últimos años, entre ellos la creciente sofisticación. Los flujos de turismo se incrementan en la medida que se generan elementos diferenciadores, los cuales se encuentran estrechamente relacionados con los factores de competitividad que algunos destinos han logrado destacar en un mundo cada vez más globalizado. Estas dinámicas, que surgen desde el lado de la demanda, han generado, entre otras, la necesidad de diferenciación del producto, donde no solo trascienden las condiciones del atractivo, sino también los llamados factores de atracción; adicionalmente, toma relevancia la experiencia que el

3 Para mayor ilustración, se recomienda una lectura de Horváth, E., \& Frechtling, D. (1999). Estimating the Multiplier Effects of Tourism Expenditures on a Local Economy through a Regional Input-Output Model. Journal of Travel Research, 37(4), 324-332. 
turista logra desarrollar en dicho lugar. En tal sentido, la necesidad de crear una oferta con alto valor agregado implica una planificación orientada a la competitividad del destino, de tal manera que sea posible fomentar los diferenciales que le permitan sobresalir en una amplia oferta mundial.

En algunas regiones, el turismo se ha venido desarrollando a partir de una concepción que busca aprovechar aquellos elementos que han sido puestos en ciertos espacios de manera aleatoria por la naturaleza o por el devenir histórico, generando una oferta a partir de estos elementos. Sin embargo, la dinámica actual del sector implica dejar de lado la connotación tradicional que define el turismo como un simple desplazamiento de un lugar a otro donde hay algo para visitar, a una en la cual los visitantes disfrutan de un producto turístico diseñado con actividades variadas que permiten su interacción y disfrute, $y$ que, por ende, generan una experiencia para el turista

Por el contrario, otras regiones o destinos han concebido el desarrollo turístico ya no como producto de la casualidad, sino como la evolución de una concepción más elaborada que depende de una interacción entre estrategias de diseño, promoción y comercialización cuidadosamente estudiadas y planificadas (Ávila y Barrado, 2005).

En el análisis realizado por Osorio (2006) a partir de la revisión de otros autores que han estudiado esta materia, se pueden identificar cuatro enfoques para la planificación turística: desarrollista, económico, espacial y estratégico. Sin entrar en el detalle de cada uno de estos enfoques, debe ser claro que una buena planificación necesita integrar los elementos más relevantes de cada uno de ellos, de tal manera que una adecuada planificación propenda por el mejoramiento de las condiciones de vida de la población en sus diversos ámbitos, genere una fuente de ingresos que impulse el desarrollo económico de un país, promueva la infraestructura física para la actividad en sí y para el disfrute de la comunidad local y, por último, integre una política de desarrollo con estrategias y acciones en curso planificadas a corto y mediano plazo.

\section{La competitividad de los destinos turísticos}

Al conjugar todos los elementos antes planteados, queda en evidencia y se refuerza la connotación del turismo como una compleja red de interacciones, las cuales, a su vez, están influenciadas por el espacio geográfico donde se desarrollan, con la intervención de elementos físicos (entre los que se encuentran los diferentes prestadores de la cadena de valor) y procesos (entendidos como planificación, gestión e imagen) que interactúan para formar la experiencia del visitante, de ahí que el producto turístico global (entendido como el conjunto de productos turísticos ofertados) está atado a la competitividad del destino o lugar donde es desarrollado (Quintero, Bernal y López, 2005).

De lo anterior se desprende que la competitividad del sector turismo está intrínsecamente vinculada con los niveles de competitividad del territorio en el cual se desarrolla, por esto la "gestión turística ya no recae exclusivamente en los tour operadores, encargados de 'empaquetar' el producto, sino que se está produciendo un proceso de traslado de la responsabilidad al propio territorio, imponiendo nuevos retos a los actores que actúan en el mismo" (Mireno y Pulido, 2009, p. 178).

Por consiguiente, el territorio y su interacción con los diversos factores de política incidirán de manera directa en la competitividad de un destino, por lo cual se hace necesaria la planificación integral a partir de la construcción de una visión de largo plazo que incluya el desarrollo de un entorno físico, tecnológico, 
social, ambiental e institucional propicio para el posicionamiento competitivo de la ciudad o región y, por ende, el mejoramiento del nivel de competitividad del destino (González y Mendieta, 2009).

Ahora bien, el estudio de la competitividad, su definición y las variables que la determinan pueden rastrearse desde diferentes autores, inicialmente ligados a los estudios económicos, y más recientemente desde el análisis organizacional de la teoría de la administración. Entre estos estudios, los avances más importantes en el desarrollo de una teoría de la competitividad son atribuidos a los planteamientos de Michael Porter, quien eleva el concepto a un nivel funcional para la comprensión de diversos fenómenos económicos, pero especialmente para el entendimiento de las diferentes industrias, entre las que se ubica el turismo. Sus estudios ponen de manifiesto la necesidad de comprender el entorno competitivo no solo desde el análisis de las ventajas absolutas, sino desde los factores que indicen sobre las ventajas competitivas que, llevadas al contexto turístico, corresponden al conjunto de variables que establecen la base competitiva del turismo en un territorio o espacio determinado.

En este sentido, el autor logra explicar la competitividad empresarial en relación con un conjunto de factores que, integrados con las decisiones de política, generan una serie de resultados, los cuales son posibles a partir de la interacción entre las empresas, el Estado y la economía en su conjunto. En sus desarrollos teóricos, el autor centra su análisis en el diamante de competitividad que incluye cuatro elementos básicos: 1) condiciones de los factores; 2) condiciones de la demanda; 3) sectores relacionados y de apoyo; 4) estrategia, estructura y rivalidad de las empresas. Son estos cuatro elementos los que, complementados con el papel del gobierno y la casualidad, determinan el desarrollo y posicionamiento competitivo de un país, región o industria (González y Mendieta, 2009).

Porter clasifica las ventajas competitivas en dos grupos: estáticas y dinámicas. Las primeras corresponden a aquellas que provienen directamente de la aglomeración geográfica, mientras que las segundas derivan de la capacidad de innovación y emprendimiento. De acuerdo con González y Mendieta (2009), estas últimas son construidas o creadas por la interacción entre las empresas, los gobiernos locales y las asociaciones o redes de ciudades, lo que implica una concepción desde el enfoque de cooperativismo (2009). No obstante, el diamante de competitividad propuesto por el autor no puede ser aplicado directamente al análisis del sector turismo, pues su naturaleza sui géneris supone un estudio diferenciado. Sin embargo, sus desarrollos teóricos recogen gran parte de la discusión académica con respecto a la definición de competitividad y se convierten en la base de otros estudios que buscan explicar y modelar los factores que influyen en la competitividad turística.

De otra parte, es necesario considerar que "la ventaja competitiva se crea y se sostiene mediante un proceso altamente localizado. Las diferencias en valores, culturas, estructuras económicas, instituciones e historias nacionales contribuyen al éxito competitivo" (Porter, 2007, p. 4). Este planteamiento refuerza el postulado que establece la necesidad de abordar la competitividad turística como una interacción compleja y dinámica que requiere la intervención decidida de todas las partes interesadas, con el fin de potenciar el sector como motor del desarrollo económico de un país o territorio, a partir del entendimiento, diagnóstico y enfoque estratégico de los diversos aspectos que intervienen en la configuración de una actividad altamente competitiva. 
Varios teóricos han abordado el estudio de la competitividad de los destinos turísticos para tratar de acuñar una definición, la cual puede variar dependiendo de la visión/perspectiva desde la cual se analice. Así, Dwyer \& Kim (2003) relacionan la competitividad de un destino con su habilidad para ofrecer bienes y servicios de una forma más eficiente de la que lo hacen sus competidores. Los llamados atributos del destino, combinados con una serie de atributos multidimensionales, pueden generar la atracción del destino, de manera que se esperaría que el turista lo eligiera por encima de otro (Khin, Daengbuppha \& Nonsiri, 2014). Sin embargo, hay unos factores más determinantes que otros al momento de la elección del destino por parte del turista (Crouch, 2011), lo cual implica tomar ventaja de aquellas oportunidades latentes con el fin de potenciarlas de tal manera que puedan hacerlo más competitivo.

El modelo propuesto por Hassan (2000) busca determinar la competitividad a partir de las partes interesadas, relacionando elementos tales como la ventaja comparativa, las condiciones de la demanda, la estructura de la industria turística y el medio ambiente. Por su parte, Dwyer \& Kim (2003) fundamentan su modelo en seis elementos claves e integrados: recursos heredados, recursos creados, recursos de soporte, condiciones situacionales, gestión del destino y condiciones de demanda.

El modelo planteado por Geoffrey Crouch y Brent Ritchie en 1999 pretende identificar y priorizar los factores que, se considera, determinan la competitividad y el éxito de los destinos turísticos, integrando el análisis de ventajas comparativas y competitivas (1999). Este modelo toma en cuenta dos entornos: uno macro o global y otro micro. El primero implica que la actividad turística se encuentra constantemente influenciada por variables exógenas, las cuales pueden ser agrupadas en seis categorías: econó- micas, tecnológicas, ecológicas, políticas y desarrollos legales, aspectos culturales y desarrollo demográfico (Sánchez y Fajardo, 2004).

En cuanto al entorno micro, este está compuesto por las organizaciones, influencias y fuerzas relacionadas directamente con la actividad turística (Ritchie \& Crouch, 1999), las cuales generan una incidencia mucho más directa que las variables de tipo macro.

En el desarrollo del modelo, los autores toman como base los conceptos de ventaja comparativa y ventaja competitiva, adaptados al contexto de la actividad turística, para formular su modelo a partir del análisis de cinco factores: 1) de atracción; 2) de soporte; 3) organización del destino; 4) política, planeamiento y desarrollo del destino; y 5) calificadores y potenciadores determinantes (Mara \& Varzin, 2008).

El factor de atracción corresponde al conjunto de elementos esenciales que constituyen los aspectos claves para la motivación del turista. Por su parte, el factor de soporte está relacionado con aquellos aspectos que permiten o posibilitan el desarrollo de actividades y de disfrute de los servicios turísticos. El tercer factor concierne a la organización del destino y los procesos necesarios para la toma de decisiones que permiten mejorar la competitividad del destino, entre los que se encuentran el recurso humano, la investigación y el desarrollo, entre otros. La política, el planeamiento y el desarrollo turístico corresponden al conjunto de aspectos que orientan la actividad, tales como la filosofía, la visión y las directrices para el desarrollo. Finalmente, los calificadores y potenciadores determinantes atañen a aspectos de localización geográfica, capacidad de carga, seguridad e imagen, costo/valor e interdependencia de los destinos (Mara \& Varzin, 2008). 
Figura 1. Modelo de Ritchie \& Crouch

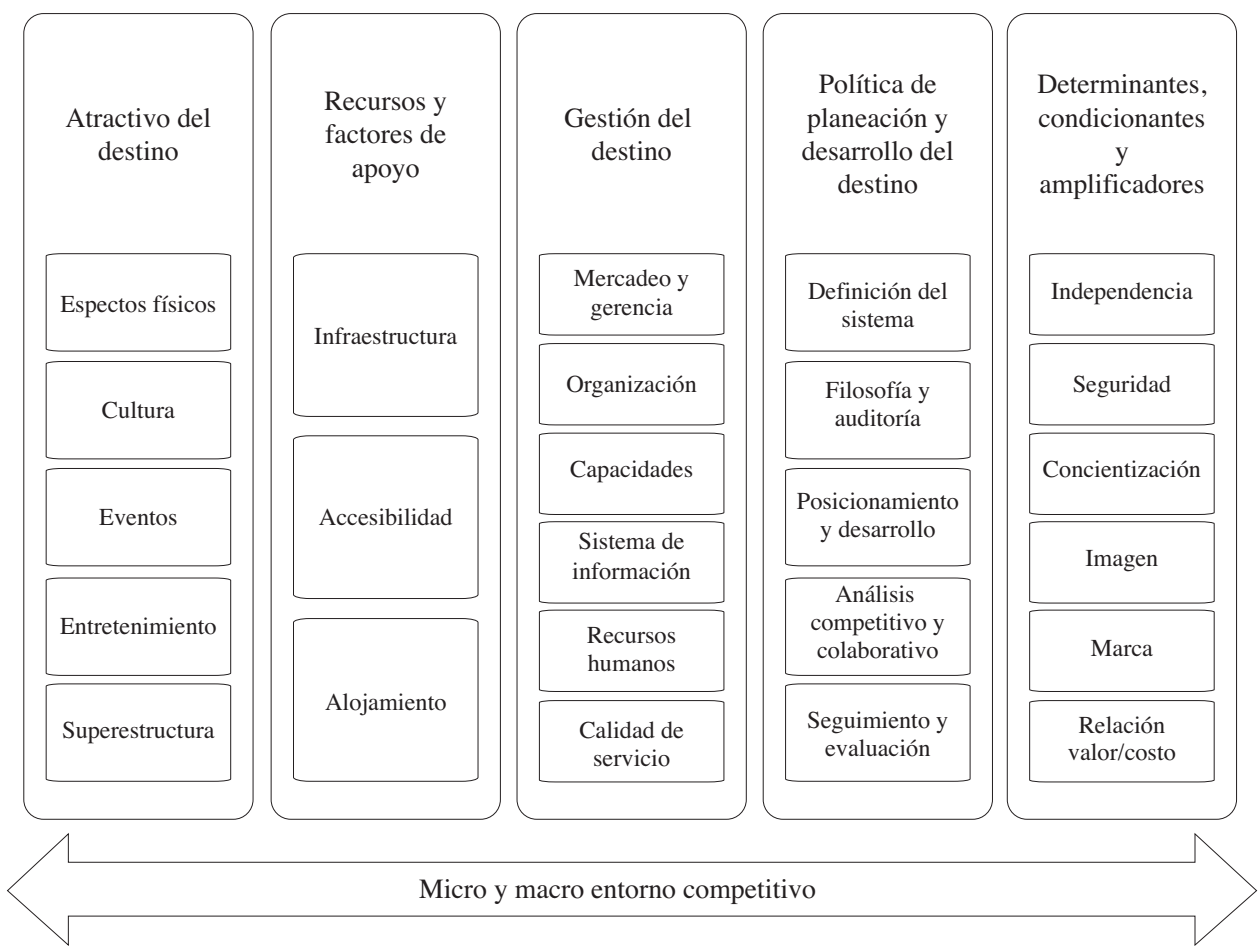

Fuente: Adaptado de Quintero, P., Bernal, C. y López, H. (2005). Serie de estudios sobre la competitividad de Cartagena. Cartagena: Cámara de Comercio.

En Colombia, los planteamientos teóricos que conceptualizan la competitividad del sector turismo son abordados por el Ministerio de Comercio, Industria y Turismo (en adelante MinCIT) en el documento de Asistencia técnica en planificación del turismo, el cual establece la competitividad de los destinos turísticos como exigencia permanente, de tal manera que se convierte en un llamado a los actores involucrados con el sector turístico colombiano a constituir procesos proactivos que conlleven al alcance de este objetivo (MinCIT, s. f.). Consecuentemente, MinCIT plantea la necesidad de considerar la competitividad del sector a partir del desarrollo y fortalecimiento de clústeres, para lo cual establece una metodología basada en los preceptos de la OMT, priorizando cuatro factores: 1) atributos de producto, 2) estruc- tura empresarial y de explotación, 3) posición en el mercado y 4) factores de producción y tecnológicos.

Lo anterior se encuentra alineado con los planteamientos de Porter, quien halla en el desarrollo de clústeres el vehículo más eficiente para el mejoramiento de las condiciones competitivas de cualquier actividad; de tal manera que, aplicado al contexto, el análisis de clústeres en el turismo corresponderá al estudio de aglomeraciones, relaciones cooperativas y competición entre los diferentes actores, cuyo objetivo principal es el de construir una industria local a partir del trabajo conjunto del sector público y del privado (Melisidou, Papageorgiou, Papayiannis \& Varvaressos, 2014). 
En lo que respecta al Esquema de planificación turística para la competitividad, también específico para el caso colombiano, se plantea la necesidad de analizar los destinos desde el enfoque de clúster, el cual se define como "un aglomerado de empresas localizadas en un mismo entorno geográfico que se identifican bien sea por su cercanía o su vocación y que se interrelacionan entre sî" (Bolinorsagua, 2012, p. 9).

Por su parte, el Plan Ambiental Turístico de Colombia plantea que para la construcción de planes de desarrollo turístico se debe partir de un "análisis de limitantes y potencialidades de cada departamento, en el que se revisen la evolución de las tipologías de turismo especializado presentes en la zona; la valoración de sus atractivos naturales y culturales; los servicios básicos requeridos; el transporte y la señalización; la arquitectura empleada; la coordinación institucional y normalización; la tecnología empleada y los recursos financieros disponibles" (Chocalán, 2012, p. 9).

Teniendo en cuenta los planteamientos teóricos desarrollados alrededor de la definición de competitividad turística, principalmente el modelo propuesto por Crouch \& Ritchie, y de manera particular las orientaciones del Esquema de planificación turística para la competitividad y el Plan Ambiental Turístico para Colombia, adaptados por el MinCIT, se elabora un marco conceptual pertinente, apropiado y ajustado al entorno de análisis del país y a las condiciones propias de cada departamento estudiado.

\section{Enfoque metodológico}

El enfoque metodológico para la formulación de los planes de desarrollo turístico de once departamentos de Colombia se basó en tres modelos: 1) el de competitividad de destinos propuesto por Crouch \& Ritchie (1999), 2) el Esquema de planificación turística para la competitividad, y 3) el Plan Ambiental Turístico para Colombia, estos últimos adaptados por el MinCIT, en el marco de la línea de Asistencia técnica en planificación del turismo, que apoya a las diferentes entidades territoriales.

Con base en los aspectos considerados, para el análisis en los once departamentos de Colombia se definieron cuatro factores claves para la competitividad de un destino: atracción, gestión, soporte y producción, los cuales habían sido considerados en el estudio adelantado por la firma Mazars Turismo para la Corporación Andina de Fomento (en adelante $\mathrm{CAF}$ ) para el análisis competitivo de los destinos consolidados que formaban parte de los países del Grupo Andino: Venezuela, Colombia, Ecuador, Perú y Bolivia (Mazars \& CAF, 2003).

Los factores de atracción conforman la materia prima de un territorio y motivan a los turistas a la realización de su viaje, por lo tanto, el éxito del destino dependerá de ellos. Los factores de gestión incorporan aspectos externos a las empresas en las que se evalúa la capacidad de los actores locales y su nivel de liderazgo para incidir en las decisiones estratégicas de los territorios, así como su capacidad de trabajo en equipo. Los factores de soporte apoyan y facilitan o limitan la calidad y capacidad de acogida; en estos se incluyen la infraestructura, la accesibilidad, la seguridad, entre otros. Por último, los factores de producción incorporan el análisis del espíritu empresarial, la presencia de prestadores de servicios turísticos y los niveles de calidad, formación e innovación tecnológica (Quintero, Bernal y López, 2005). 
Figura 2. Adaptación de la CAF al modelo de Ritchie \& Crouch

Competitividad y sostenibilidad del destino

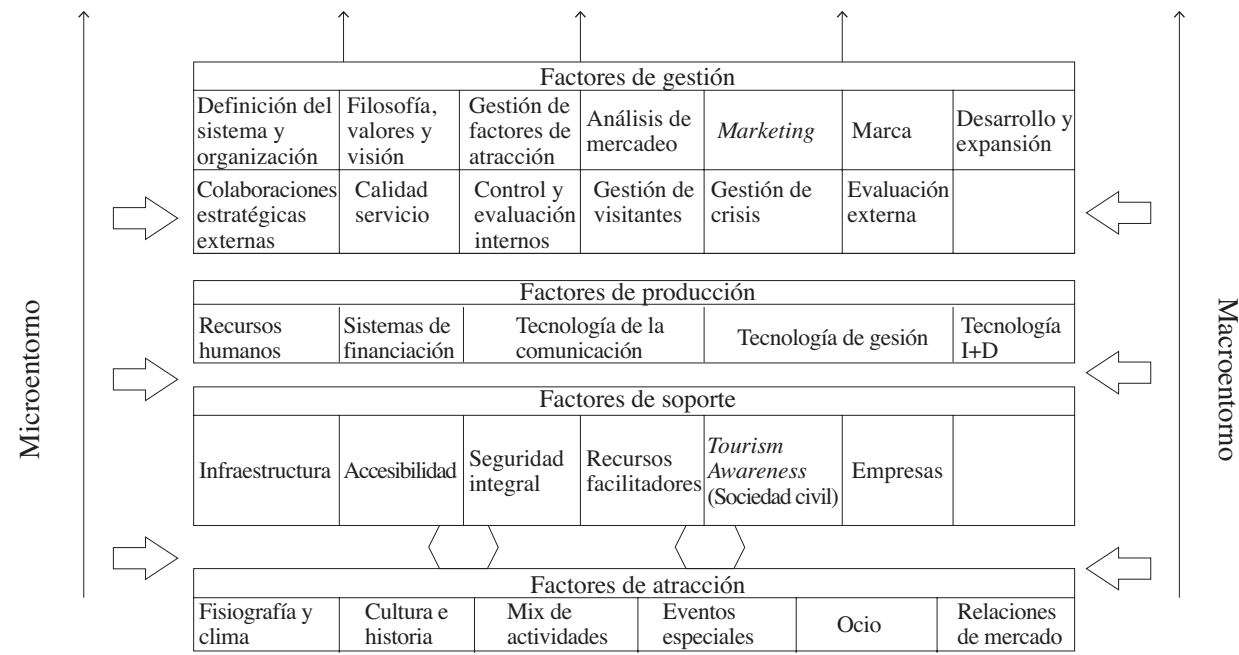

Fuente: Mazars Turismo \& CAF, 2003.

En este orden de ideas, para el desarrollo de anteriores, considerando los factores adapeste estudio se integraron las tres propuestas tados del modelo de Ritchie \& Crouch, así:

Figura 3. Modelo metodológico del estudio

Plan de desarrollo turístico: modelo

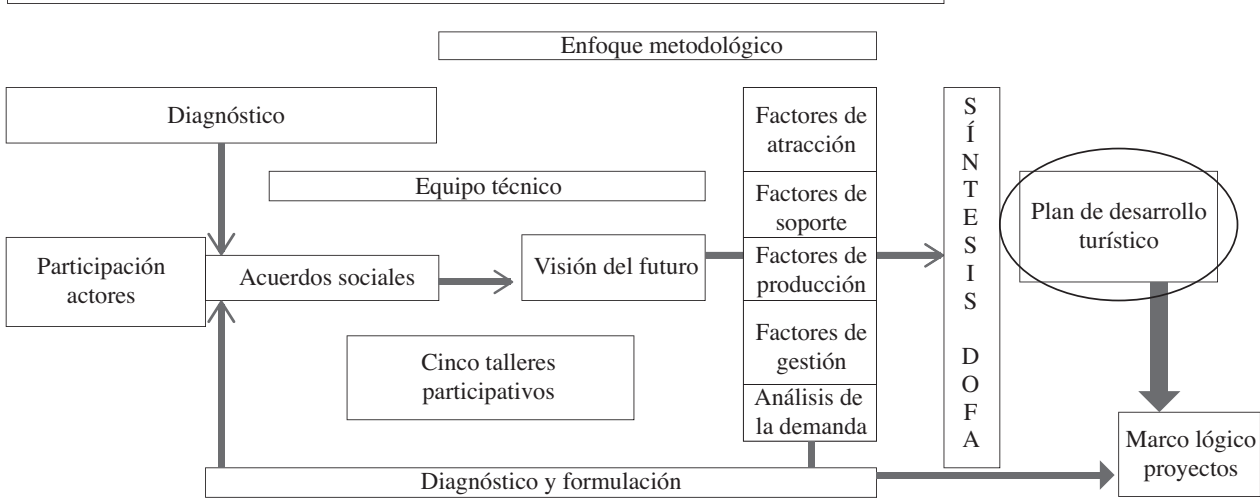

Fuente: Uniones Temporales de Turismo, 2012.

La Unión Temporal de Turismo (UTT) se organizó a su vez en cuatro uniones temporales que agrupaban un número específico de departamentos. Cada una de ellas estaba conformada por un grupo técnico de expertos y tenía distinta denominación, así: 
Tabla 1. Denominación Uniones Temporales de Turismo (UTT) por departamentos

\begin{tabular}{|l|l|l|l|}
\hline \multicolumn{1}{|c|}{$\begin{array}{c}\text { UTT } \\
\text { BOLINORSAGUA }\end{array}$} & \multicolumn{1}{c|}{$\begin{array}{c}\text { UTT } \\
\text { CUNDISAN }\end{array}$} & \multicolumn{1}{c|}{$\begin{array}{c}\text { UTT } \\
\text { HUITONAVA }\end{array}$} \\
\hline Norte de Santander & Cundinamarca & Huila & Antioquia \\
\hline Bolívar & Santander & Tolima & Caldas \\
\hline La Guajira & & Nariño & Chocó (no se finalizó el plan) \\
\hline & & Valle & \\
\hline
\end{tabular}

Fuente: Elaboración propia a partir de la constitución de las Uniones Temporales de Turismo (2012), 2014.

El enfoque metodológico propuesto por el equipo de trabajo partía de la premisa de que los procesos de planificación deben ser construidos, concertados y avalados por los actores sociales de cada destino en el que se adelanta el proceso de intervención. Para ello, se organizó el equipo con la participación directa de actores locales que coordinaron y realizaron las convocatorias en cada departamento, y se incluyeron expertos temáticos que aportaron al trabajo transversal en las diferentes zonas consideradas en el estudio.

Figura 4. Equipo interdisciplinario y con participación local

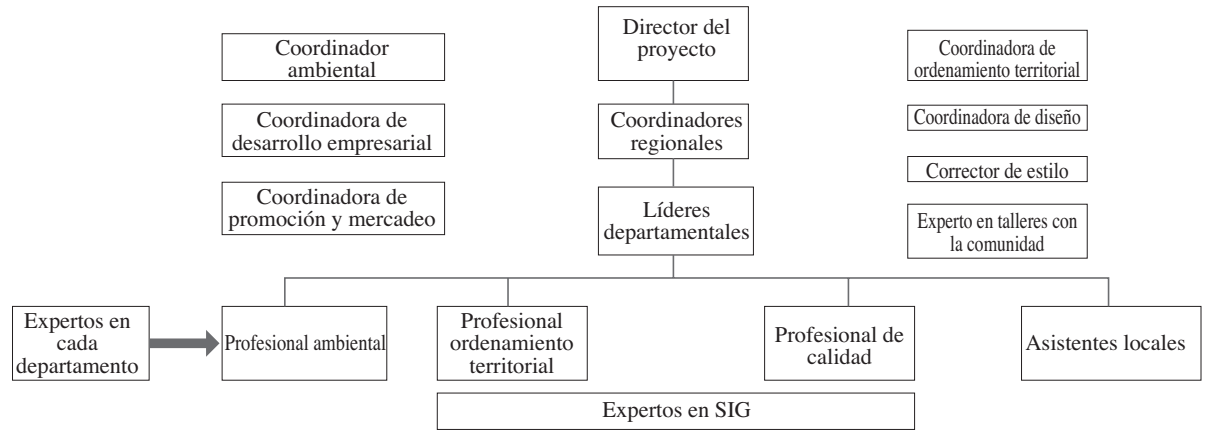

Fuente: Unión Temporal de Turismo, 2012.

Si bien el modelo metodológico se fue ajustando a las condiciones particulares de cada departamento, las líneas temáticas y el enfoque de competitividad y sostenibilidad se mantuvieron en general, de tal manera que se pudiera contar con una perspectiva nacional de desarrollo regional de destinos. Así mismo, por medio de cinco talleres de trabajo en cada departamento, y conjuntamente entre el equipo técnico y los actores de cada departamento, se formularon el diagnóstico y el componente estratégico, partiendo de la base de que las diversas perspectivas y realidades sobre el desarrollo turístico deben generarse mediante la negociación de los intereses y las visiones diversas, por lo cual, el proceso se adelantó de manera concertada con los grupos de trabajo en cada zona a partir de talleres descentralizados, es decir, en los municipios más importantes y en la capital de cada departamento.

Para cada factor se propuso una metodología que combinó el análisis de fuentes secundarias y la aplicación-análisis de instrumentos de recolección de información primaria, como se detalla en el anexo 1.

A continuación se describen brevemente los componentes considerados en cada factor: 


\section{A. Factor de atracción}

Se incluye el análisis de los siguientes aspectos:

Figura 5. Criterios del factor de atracción

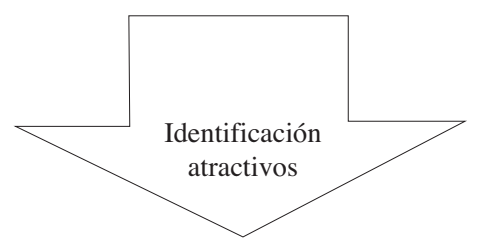

Revisión de los atractivos reales y potenciales.

Valoración cualitativa de percepción.

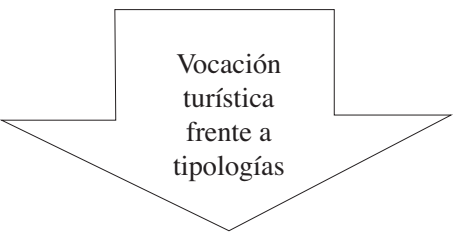

Análisis de la potencialidad según criterios de competitividad y sostenibilidad.

Categorización y valoración mediante definición de microclúster, clúster, rutas y demás.

Georreferenciación POT y SIG: preselección microclústers y clúster.

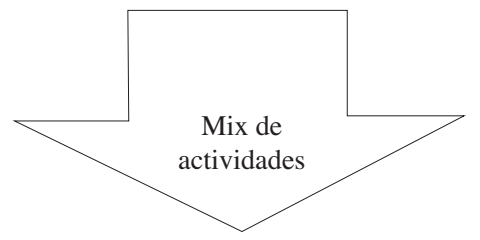

Identificación de actividades según selección.

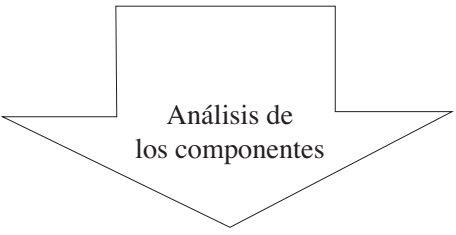

Valoración ambiental: impactos y de usos frente a actividades.

Valoración de elementos culturales tangibles e intangibles.

Fuente: Unión Temporal de Turismo, adaptando el modelo de Ritchie \& Crouch, 2012.

Se partió de la evaluación del inventario de atractivos turísticos de cada departamento, para lo cual se consideraron los siguientes criterios de valoración por cada uno de ellos: 
Tabla 2. Criterios de valoración de atractivos

\begin{tabular}{|c|c|}
\hline Aspecto & Ponderación \\
\hline Grado de conservación & $17 \%$ \\
\hline $\begin{array}{l}\text { Servicios de apoyo (facilidades en el lugar: restaurantes, guía in situ, folletos, interpretación en el } \\
\text { lugar, etc.). }\end{array}$ & $13 \%$ \\
\hline Estado de las vías de llegada. & $4 \%$ \\
\hline \multicolumn{2}{|l|}{ Significado del atractivo: } \\
\hline Internacional & $13 \%$ \\
\hline Nacional & $8 \%$ \\
\hline Regional & $4 \%$ \\
\hline Local & $2 \%$ \\
\hline $\begin{array}{l}\text { Condiciones actuales de gestión del atractivo: capacidad organizativa para la gestión permanente } \\
\text { del atractivo, grado de responsabilidad de actores públicos o privados en su administración. }\end{array}$ & $12 \%$ \\
\hline Valoración de los horarios de apertura en el atractivo. & $8 \%$ \\
\hline $\begin{array}{l}\text { Nivel de promoción del atractivo: aparición en material promocional del destino, estrategia per- } \\
\text { manente de publicidad, página web, etc. }\end{array}$ & $13 \%$ \\
\hline Declaratorias especiales: bien de interés cultural (BIC), reserva, área protegida, etc. & $14 \%$ \\
\hline Condiciones de seguridad en el entorno o para la visita al atractivo. & $6 \%$ \\
\hline Total & $100 \%$ \\
\hline
\end{tabular}

Fuente: Unión Temporal de Turismo, 2012.

Una vez calificados, se seleccionaron aquellos que obtuvieron una calificación por encima de 3,5. Sin embargo, por selección intencional, se incluyeron adicionalmente aquellos atractivos que, si bien no alcanzaron dicha nota, contasen con un alto potencial de atracción a mediano o largo plazo, aunque en aquel momento no tuviesen las condiciones de soporte o de conectividad que facilitasen la llegada a estos, por ejemplo, algunos parques nacionales o centros históricos declarados por la nación como bienes de interés cultural (BICN). Posteriormente, con un listado bien nutrido de atractivos turísticos fruto de la anterior selección, se propuso una clasificación de los componentes del modelo de competitividad en cada departamento, de acuerdo con los resultados del análisis de fuentes secundarias y primarias, así:

- Grado de madurez del destino.

- Grado de conectividad, accesibilidad.

- Presencia de estructura empresarial.

- Vocación por tipologías de turismo.

- Grado de atractividad.

A partir de estos criterios, se propuso la siguiente clasificación: 
Tabla 3. Categorización del territorio

\begin{tabular}{|c|c|c|c|}
\hline Clúster $^{*}$ & Microclúster $^{* *}$ & Ruta*** & Circuito $^{* * * * *}$ \\
\hline $\begin{array}{l}\text { Oferta relativamente homogé- } \\
\text { nea de atractivos localizados en } \\
\text { un mismo espacio geográfico. } \\
\text { Existencia de demanda conso- } \\
\text { lidada. } \\
\text { Estructura empresarial conso- } \\
\text { lidada. } \\
\text { Conectividad y accesibilidad. } \\
\text { Potencial internacional. }\end{array}$ & $\begin{array}{l}\text { Factor de atractividad sig- } \\
\text { nificativo. } \\
\text { No necesariamente estructu- } \\
\text { ra empresarial. } \\
\text { Accesibilidad y conectivi- } \\
\text { dad mínima. } \\
\text { No necesariamente ligado a } \\
\text { un clúster. } \\
\text { Demanda aún incipiente. }\end{array}$ & $\begin{array}{l}\text { El recorrido inicia en un } \\
\text { punto A y puede llegar } \\
\text { a un punto B atravesan- } \\
\text { do uno o varios sitios } \\
\text { de interés turístico o } \\
\text { atractivos. }\end{array}$ & $\begin{array}{l}\text { Punto de entrada y sali- } \\
\text { da en el mismo lugar en } \\
\text { recorrido circular. } \\
\text { Puede unir varios sitios } \\
\text { de interés turístico y/o } \\
\text { atractivos. }\end{array}$ \\
\hline
\end{tabular}

* "Espacio geográfico homogéneo donde se hallan concentrados atractivos turísticos, infraestructuras, equipamientos y empresas turísticas, en el cual estas pueden establecer relaciones positivas y en cuyo ambiente tienen lugar las experiencias turísticas". (Huitonava U. T., 2012, p. 11)

** “La concentración geográfica de un pequeño número de empresas, productos y servicios turísticos, en el cual existe un atractivo potente, real o potencial, lo que permite la confección de un producto especializado y una experiencia singular para el turista/ visitante". (Huitonava U. T., 2012, pp. 11-12)

*** "Un trayecto en el cual el turista recorre uno o varios sitios de interés turístico, partiendo de un lugar determinado y llegando a un lugar diferente". (Huitonava U. T., 2012, p. 112).

***** "El trayecto incorpora varios sitios de interés turístico, partiendo y regresando al mismo lugar de origen". (Huitonava U. T., 2012, p. 11).

****** Propuestas detalladas por clústeres, microclústeres, rutas y circuitos en cada departamento.

Fuente: Unión Temporal de Turismo, 2012.

Simultáneamente, se adelantaron las siguientes actividades:

1. Revisión de la oferta turística de cada departamento ofrecida en guías turísticas, tanto nacionales como internacionales, $\mathrm{y}$ revisión de las ofertas comerciales presentes en páginas web de agencias de viajes o de buscadores turísticos.

2. Revisión del inventario turístico de cada departamento, para cruzar la información de los atractivos inventariados con los atractivos promocionados en las guías y en las agencias.

3. Validación de la información encontrada con los líderes departamentales e inclusión de aquellos atractivos con alto potencial turístico, pero que no aparecen en guías ni en ofertas comerciales. Esta selección se cruzó con los atractivos ya seleccionados de la valoración de inventarios que se explicó anteriormente.
4. Visita de reconocimiento por parte de los expertos en mercadeo y de los coordinadores regionales del proyecto que formaban parte del equipo técnico.

5. Ubicación de los atractivos seleccionados en el mapa departamental, con el fin de determinar los municipios donde se localizaban.

6. Determinación de los clústeres, microclústeres, circuitos y rutas, atendiendo a criterios de atractividad, homogeneidad de la oferta y articulación.

7. Taller de validación de los clústeres y microclústeres, con los actores turísticos de cada departamento.

8. Definición de un mix de actividades para cada departamento por tipologías identificadas.

Una vez se seleccionaron los clústeres, microclústeres, las rutas y los circuitos, se 
adelantó el análisis de los componentes de ordenamiento territorial y ambiental de cada departamento, para lo cual se revisaron fuentes secundarias y se avanzó también en un trabajo de campo que permitió una aproximación a las condiciones actuales de cada uno de estos aspectos.

A partir de esta categorización, se analizó el resto de factores que propone el modelo (soporte, producción y gestión).

\section{B. Factor de soporte}

Se realizó un análisis de antecedentes del turismo, para lo cual se consideraron los convenios de competitividad existentes (documentos de compromisos firmados entre cada departamento y el Gobierno nacional) y su nivel de ejecución, los adelantos de los consejos regionales de competitividad, la existencia o no de planes de desarrollo turístico que se hubiesen formulado anteriormente, el nivel de involucramiento del turismo en los planes de desarrollo departamentales o municipales y otros estudios previos, políticas de turismo (marco legal), entre otros.

Figura 6. Criterios del factor de soporte

\begin{tabular}{|c|c|}
\hline \multicolumn{2}{|c|}{ Antecedentes } \\
\hline $\begin{array}{c}\text { Análisis convenios de } \\
\text { competitividad y conse- } \\
\text { jos regionales. }\end{array}$ & $\begin{array}{c}\text { Planes de desarrollo de- } \\
\text { partamental y planes de } \\
\text { desarrollo turístico. }\end{array}$ \\
\hline \begin{tabular}{c} 
Condiciones del entorno \\
\hline Análisis sintético de las condiciones económicas, \\
sociales y problemáticas.
\end{tabular} \\
\hline \\
\hline $\begin{array}{c}\text { Conectividad y accesibilidad } \\
\text { formación, uso de medios virtuales y condiciones de } \\
\text { acceso para discapacitados. }\end{array}$ \\
\hline
\end{tabular}

Fuente: Unión Temporal de Turismo, 2012.

Así mismo, se realizaron entrevistas en profundidad a expertos en infraestructura, con el fin de recopilar información relacionada con su estado actual. También se valoraron las condiciones económicas, sociales y políticas generales del departamento, que, como componentes del entorno, podrían llegar a afectar la competitividad turística en cada departamento.

Con base en fuentes secundarias, se revisó el estado actual de la conectividad y la accesibilidad, considerando la aérea, terrestre y virtual, así como las condiciones de la infraestructura de alcantarillado, energía y acueducto, y los indicadores generales de seguridad en los destinos.

En relación con el análisis de la cultura turística, se aplicó una encuesta a los participantes en los talleres, con el fin de establecer el grado de aceptación y de actitud frente al turista, así como el conocimiento y disposición hacia el turismo por parte de la comunidad receptora. Se evaluó si hay una buena acogida o rechazo al visitante. Así mismo, se valoraron las incidencias que esta actividad podría generar.

\section{Factor de producción}

Para el análisis de los prestadores de servicios turísticos, y con el fin de conocer la realidad empresarial de los destinos, se construyeron muestras estadísticas con base en la información recabada tanto del Registro Nacional de Turismo (RNT) como de aquellas empresas que, aun sin estar debidamente formalizadas, prestan servicios y son frecuentadas por visitantes y turistas. El objetivo era aplicar una encuesta mediante la cual se determinara el nivel de calidad, los grados de formación y cualificación del recurso humano, la existencia de sistemas de innovación y desarrollo tecnológico y la implementación o ausencia de algunos criterios de sostenibilidad.

Igualmente, con base en las normas técnicas sectoriales, se diseñaron listas de chequeo en las que se incorporaron aquellos estándares 
de sostenibilidad de mayor relevancia. Estas listas de chequeo fueron aplicadas a la muestra de empresarios turísticos seleccionados. Mediante visitas técnicas se indagó acerca de sistemas gerenciales en lo relacionado con uso de tecnologías, cultura organizacional, comportamiento financiero de las empresas, comercialización y venta, competencia del recurso humano y adopción de esquemas de calidad.

A continuación se muestra una ilustración en la que se evidencian las diferentes variables analizadas en este factor:

Figura 7. Criterios del factor de producción

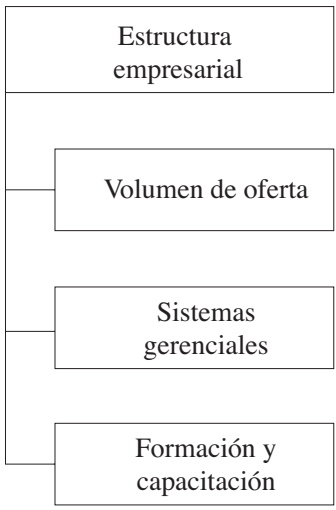

Fuente: Unión Temporal de Turismo, 2012.

El total de la muestra ascendió a 1063 prestadores, de los cuales el 92,9\% cumplió el requisito del Registro Nacional de Turismo; los departamentos con mayor nivel de formalidad fueron Huila, Cundinamarca y Antioquia, con 98,9\%; en tanto que La Guajira, Norte de Santander y Tolima fueron los departamentos que presentaron altos índices de informalidad, con $23,1 \%, 20 \%$ y $16 \%$, respectivamente.

\section{Factor de gestión}

En este factor se revisaron fuentes secundarias relacionadas con la gestión y el marketing del destino, principales canales de promoción y comercialización. En el marco anterior se efectuaron sondeos de opinión a turistas que visitaron cada departamento durante el periodo establecido para dicha recolección de información (aprox. 100 por departamento). 
Figura 8. Criterios del factor de gestión

\begin{tabular}{|c|}
\hline $\begin{array}{c}\text { Gestión del marketing } \\
\text { del destino }\end{array}$ \\
\hline $\begin{array}{c}\text { Análisis y nivel de } \\
\text { fidelidad de la demanda }\end{array}$ \\
\hline $\begin{array}{c}\text { Nivel de concentración } \\
\text { de la demanda }\end{array}$ \\
\hline Nivel de precios \\
\hline $\begin{array}{c}\text { Canales de } \\
\text { comercialización }\end{array}$ \\
\hline $\begin{array}{l}\text { Nivel de notoriedad } \\
\text { en el mercado }\end{array}$ \\
\hline
\end{tabular}

\begin{tabular}{|c|}
\hline $\begin{array}{c}\text { Gestión turística } \\
\text { del destino }\end{array}$ \\
\hline $\begin{array}{c}\text { Mapa de actores } \\
\text { estratégicos }\end{array}$ \\
\hline $\begin{array}{c}\text { Organización de } \\
\text { gestión del destino }\end{array}$ \\
\hline
\end{tabular}

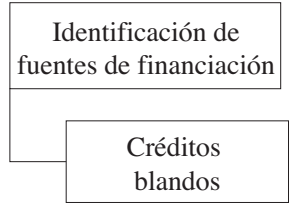

Fuente: Unión Temporal de Turismo, 2012.

Adicionalmente, se realizó un estudio de la demanda potencial ${ }^{4}$, para lo cual se aplicaron encuestas en las cinco principales ciudades emisoras de mercado para los diversos destinos de Colombia. El diseño de la muestra se especifica en la siguiente ficha técnica:

Tabla 4. Ficha técnica de estudio de demanda potencial

\begin{tabular}{|l|l|c|c|}
\hline \multirow{3}{*}{\begin{tabular}{c} 
Método \\
\multirow{4}{*}{ Distribución del instrumento }
\end{tabular}} & \multicolumn{2}{|c|}{$\begin{array}{r}\text { El diseño muestral se realizó bajo el método aleatorio simple (MAS), } \\
\text { con una muestra total de 1050 personas encuestas. }\end{array}$} \\
\cline { 2 - 4 } & Medellín & 223 & $7 \%$ \\
\cline { 2 - 4 } & Bogotá & 237 & $6 \%$ \\
\cline { 2 - 4 } & Cali & 219 & $7 \%$ \\
\cline { 2 - 4 } & Barranquilla & 186 & $7 \%$ \\
\cline { 2 - 4 } & Bucaramanga & 185 & $7 \%$ \\
\cline { 2 - 4 } & Total & 1.050 & $3 \%$ \\
\hline
\end{tabular}

*Error muestral para la estimación de proporciones, en MAS, con un $95 \%$ de confiabilidad, asumiendo $\mathrm{p}=0.5$.

** Las conclusiones solo son aplicables para la muestra y no pueden ser generalizadas para la población de referencia.

Fuente: Elaboración propia a partir de Unión Temporal de Turismo, 2012.

4 Ver ficha técnica del estudio de demanda potencial realizado en el marco de la investigación. 
De otra parte, se valoró la gestión turística del destino, para lo cual se diseñó un mapa de actores estratégicos y se evaluaron cualitativamente las relaciones entre actores, es decir, turistas, comunidad receptora, empresarios y sector público, a partir de la aplicación de una encuesta a los principales líderes de opinión relacionados con el turismo en cada departamento.

Una vez se elaboró el análisis en el que se incorporaron los cuatro factores mencionados, se procedió a realizar un diagnóstico de debilidades, oportunidades, fortalezas y amenazas (DOFA). Posteriormente, se procedió a formular el componente estratégico del plan, para lo cual se utilizó la metodología de marco lógico, que incluye objetivos, estrategias, proyectos, acciones, responsables e indicadores de seguimiento y evaluación.

A continuación se presentan, de manera sintética, los principales análisis derivados de la aplicación del enfoque metodológico descrito en páginas anteriores, así como los principales resultados de cada uno de los factores para los once departamentos, esto con el ánimo de establecer una tendencia nacional.

\section{Análisis de los factores}

\section{Factores de atracción}

El objetivo principal a la hora de analizar este factor es identificar los principales clústeres, microclústeres, rutas y circuitos turísticos, la vocación turística y su correspondiente mix de actividades en cada departamento.

Cabe anotar que la oferta de atractivos se concentra en a) sitios de interés natural dentro de los cuales se destaca el Sistema Nacional de Áreas Protegidas, algunos de ellos en excelente estado de conservación; b) los centros históricos con diversidad en términos de la calidad y tipo de oferta, algunos con una alta incidencia y transformación urbanística, que han afectado considerablemente sus valores culturales e identitarios; c) sitios de interés basados en la tematización, que aparecen como oferta relativamente reciente (de aproximadamente unos veinte años hacia atrás), dando, en algunos casos, valores agregados a los destinos. Los valores asociados más representativos evidencian el potencial para diseñar en el futuro productos turísticos especializados y diferenciados, pero, como se verá más adelante en el análisis de los demás factores, se requiere de apoyo en innovación, capacitación, adecuación de infraestructuras, incorporación de buenas prácticas en sostenibilidad tanto en los territorios como en los prestadores, entre otros aspectos, para contar con una oferta de alta calidad y en la que participen los actores locales de manera activa y con liderazgo.

Es evidente que los valores representativos en muchos casos están asociados a manifestaciones culturales como la oferta gastronómica, la artesanal y las expresiones musicales que, sin embargo, requieren, en términos generales, de mayor puesta en valor, excepción hecha de clústeres ya consolidados, especialmente localizados en centros urbanos del país.

En términos generales, los departamentos analizados necesitan mayores adecuaciones en infraestructuras -como vías de acceso, información, señalización y servicios de apoyo en los atractivos- y algunos aspectos puntuales, por ejemplo, adecuación de parqueaderos, servicios sanitarios para visitantes, senderos, miradores, entre otros.

Si bien empiezan a aparecer actividades experienciales en algunos destinos, es evidente la ausencia de productos turísticos o de actividades relacionadas con las emociones o las experiencias, así como bienes y o de apoyo que redunden en una oferta comercial consistente con la vocación de los diversos destinos. En algunos casos es necesaria una 
mayor cualificación en aspectos tales como alojamiento, alimentación, guianza y transporte especializado; manipulación técnica y manejo higiénico de los alimentos; personal bilingüe; normas estrictas de seguridad, por ejemplo, para el caso de deportes extremos, y formalidad en la prestación de los servicios. Se advierte también la ausencia de material de apoyo, como guías impresas o digitales de buena calidad en los departamentos, y se requiere la necesidad de fortalecimiento de la capacitación de los prestadores de servicios turísticos. Todos estos elementos se revelan en el análisis de las tendencias encontradas en el factor gestión.

El anexo 2 presenta la vocación turística principal y secundaria de cada departamento, la tipología de turismo asociada, las actividades y los valores relacionados a los departamentos. Adicionalmente, en el anexo 3 se identifican los principales atractivos, y en el anexo 4 se expone el mix de actividades derivado de lo anterior. Cabe destacar que todos estos aspectos fueron consensuados con los actores estratégicos de los departamentos.

\section{Factores de soporte}

Siguiendo el planteamiento teórico y metodológico descrito en la primera parte de este documento, se realiza el análisis del factor de soporte. En tal sentido, a continuación se muestra un compendio de los antecedentes, condiciones del entorno y estado de la conectividad y accesibilidad para cada uno de los departamentos incluidos.

\subsection{Condiciones económicas, sociales, po- líticas y generales de los departamentos}

El análisis de la información recolectada muestra una diversidad en el desarrollo de actividades económicas en los diferentes departamentos incluidos en este estudio. En su mayoría, basan sus economías en el desarrollo de actividades primarias, tales como la agricultura y la explotación de recursos naturales, mientras que otros departamentos, por ejemplo, Antioquia, Valle del Cauca y Cundinamarca, revelan un mayor peso en actividades relacionadas con los servicios y la manufactura. Se constata de manera general un crecimiento considerable de los diferentes sectores y los PIB departamentales, impulsados por un buen desempeño de la economía nacional en los últimos años. En el caso del departamento de Norte de Santander, se demuestra una fuerte incidencia a partir de la crisis de 2010 en la frontera con Venezuela, situación que afectó considerablemente a los sectores económicos de este y otros departamentos.

En síntesis, los siguientes enunciados corresponden a los principales problemas que afectan a los departamentos analizados, que si bien forman parte del entorno macroeconómico, terminan afectando la actividad turística, dadas las relaciones que esta tiene con los demás sectores de la economía:

a. Bajo nivel de productividad de los departamentos.

b. Mal estado o ausencia de la infraestructura de conectividad terrestre.

c. Baja calidad y poca cobertura de los servicios públicos.

d. Baja capacidad gerencial de los empresarios.

e. Bajo presupuesto para el desarrollo de proyectos de inversión de alta incidencia.

f. Altos niveles de informalidad en los sectores productivos.

g. Desarrollo de actividades con alto deterioro del medio ambiente. 
h. Altos niveles de desempleo, pobreza y desigualdad social.

\subsection{Antecedentes de la planificación turística}

La planificación turística es un factor fundamental para el desarrollo de una estrategia de competitividad, por tal razón, los destinos deben propender por el desarrollo de una cultura de la planificación orientada a la competitividad por medio del trazado de lineamientos con una visión de futuro, de tal manera que permita el avance de los territorios en los cuales el turismo ejerce una influencia para el desarrollo local.

En este orden de ideas, los once planes de desarrollo elaborados demuestran una gran variedad de antecedentes en la planificación de los destinos y dejan entrever la apuesta de cada uno de los departamentos y del país por el desarrollo de un sector que cada día toma mayor importancia para la economía nacional y departamental.

Los planes regionales de competitividad, instrumento desarrollado por el Gobierno nacional, aparecen como común denominador en los once departamentos. Estos planes establecen las orientaciones, normas, actividades, recursos, programas e instituciones públicas y privadas para la materialización de la estrategia nacional para el impulso de la competitividad de las regiones (Bolinorsagua, 2012).

Es interesante que en departamentos como Cundinamarca y Huila se nota un gran número de antecedentes en planificación turística a nivel de municipios y especialmente de regiones, de manera que se constituyen en una primera base para el desarrollo del clúster alrededor de la actividad turística.

Algunos departamentos han construido sus políticas de planificación turística a partir de la visión que cada ente territorial ha desarrollado. Las expresiones que promulgan la actividad turística como un eje estratégico para alcanzar diversos objetivos de desarrollo son recurrentes en estas visiones, de tal manera que esto se ha traducido en estrategias regionales para el impulso del turismo.

También surgen antecedentes desde los diagnósticos previos realizados. Tal es el caso del estudio de competitividad del sector turismo para Cundinamarca, realizado en 1996, entre otros ejemplos, el cual aborda el análisis del sector a partir del análisis del clúster de ecoturismo, e identifica las ventajas competitivas del clúster y, de manera general, presenta un diagnóstico del desarrollo de la industria del ecoturismo en esta región del país (Cundisán U.T., 2012).

\subsection{Marco regulatorio}

En línea con lo antes expuesto, se encuentra un muy variado y extenso marco regulatorio para el desarrollo de la actividad turística. Se evidencia la preocupación, tanto del nivel ejecutivo como del legislativo, por organizar el sector y establecer normas para su debido desarrollo. Para ampliar el análisis desde este importante marco, se invita al lector a revisar el anexo 5.

\subsection{Conectividad y accesibilidad}

La conectividad y accesibilidad de cada uno de los departamentos se analiza con base en cinco componentes: terrestre, aéreo, marítimo y fluvial, férreo y virtual, tecnológico y de acceso a la información.

En cuanto a la conectividad terrestre, algunos departamentos, tales como Antioquia y Cundinamarca, muestran alto desarrollo de infraestructura en comparación con Nariño, que señala los mayores problemas en este 
aspecto, con un gran número de vías en mal estado y/o en proceso de construcción. Todos los departamentos cuentan con conectividad terrestre con el resto del territorio nacional por medio de las empresas de transporte que se localizan o prestan su servicio, la mayoría de tipo interdepartamental, así como un bajo número a nivel interno (únicamente entre los municipios del departamento).

En relación con la conectividad aérea, todos los departamentos cuentan con al menos un aeropuerto que los comunica con el resto del país. Sin embargo, es notoria la ubicación de algunos aeropuertos, tales como Eldorado de Bogotá, "Rafael Núñez" de Cartagena o el "José María Córdoba" en Rionegro, frente a otros, como "La Nubia” en Manizales y “Antonio Nariño" en Chachagüí, donde el tráfico y la infraestructura instalada es considerablemente menor. Algunos departamentos tienen un tipo de pista intermedia (nivel regional), con menor capacidad y, en la mayor parte de los casos, sin óptimas condiciones.

En cuanto a la conectividad férrea, esta se limita fundamentalmente al transporte de carga, de tal forma que su desarrollo está vinculado con el avance de las actividades que hacen uso de esta, exceptuando el llamado Tren de la Sabana en el departamento de Cundinamarca, cuya oferta se basa en recorridos turísticos.

La conectividad marítima y fluvial está principalmente desarrollada en los departamentos de Bolívar y Valle del Cauca, siendo Cartagena el principal puerto para el arribo de cruceros al país. Los demás puntos de acceso con los que cuentan los departamentos se encuentran con un muy bajo nivel de desarrollo, la mayor parte descuidados y con deficiencias en sus instalaciones, como es el caso del puerto de La Dorada en el departamento de Caldas. En otros casos, por ejemplo, Cundinamarca, la conectividad fluvial se ve limitada por problemas ambientales que restringen la navegabilidad.
Finalmente, la conectividad virtual, tecnológica y de acceso a la información es quizá la más desarrollada en cada uno de los departamentos analizados, y alcanza sus mayores niveles en los departamentos de Antioquia y Cundinamarca, donde la penetración de Internet y la cobertura de telefonía fija y móvil son buenas. En esta materia, se resalta la iniciativa del Ministerio de Tecnologías de la Información y las Comunicaciones, que ha logrado aumentar considerablemente el acceso en los diferentes departamentos. Sin embargo, aún existen rezagos de conectividad en zonas apartadas, donde esta es limitada, sobre todo en zonas rurales.

\subsection{Infraestructuras}

El alcantarillado, el acueducto y la energía eléctrica muestran altos niveles de cobertura en las áreas urbanas; no obstante, el diagnóstico es considerablemente diferente en el área rural, donde se presentan problemas de cobertura, principalmente en el acceso al servicio de acueducto. En el caso puntual del departamento de La Guajira, la infraestructura de servicios públicos se considera regular, dada la deficiencia que se presenta en algunos municipios del departamento, especialmente en la cobertura de acueducto y alcantarillado. En cuanto a la infraestructura hospitalaria, se resalta la existencia, aunque no en igual proporción y condiciones, de hospitales, clínicas y centros de salud en cada uno de los departamentos, incluyendo los cuatro niveles de complejidad.

\subsection{Seguridad}

En relación con la seguridad, todos los departamentos cuentan con presencia del Ejército Nacional, la Policía Nacional (incluyendo Policía de Turismo). Sin embargo, aunque los indicadores muestran un avance en el mejoramiento de las condiciones de seguridad en 
los diferentes departamentos, aún persisten altos niveles de inseguridad en los delitos de alto impacto, tales como hurto a personas, vivienda, vehículos y delitos contra la vida. Se resalta en este aspecto el continuo trabajo por parte de la Policía en el mejoramiento de la seguridad ciudadana.

\subsection{Comunidad receptora}

A partir de la encuesta aplicada a los diversos actores del turismo, se indaga por conocer el grado de cultura turística en cada departamento. La gráfica que se incluye en la página siguiente se construye a partir del promedio de las calificaciones de cada uno de los departamentos en cada una de las variables analizadas, de manera que al identificar el nivel de desarrollo de la cultura turística en el país, se observa lo siguiente:

a. Los actores encuestados coinciden en calificar como muy bajo el desarrollo de una cultura turística en la población. En tal sentido, el $12 \%$ percibe que el desarrollo de dicha cultura no es suficiente, traducido en una desapropiación de la comunidad.

b. El recurso humano muestra ser insuficiente; el $26 \%$ de los encuestados considera que el talento humano en el sector es adecuado. Por otra parte, se pone en evidencia la percepción de los encuestados en cuanto a la falta de orientación de este hacia el turista, lo cual puede ver seriamente comprometido el desarrollo del sector. No obstante, en relación con la formación y capacitación del personal que labora en el sector, se muestran resultados aceptables, alcanzado una calificación de $61 \%$. c. Se evidencia un desconocimiento de la comunidad local de la oferta turística de su propio municipio. En relación con el conocimiento de la ciudad y la oferta de atractivos, el $37 \%$ de los encuestados considera que la comunidad tiene apropiación de conocimiento, mientras que el $46 \%$ afirma que la comunidad sí conoce la oferta de servicios de alojamiento y restaurantes que se ofrece al turista. Sin embargo, en cuanto a la identificación de variables que se relacionan con la identidad del destino y que, por ende, atraen al turista, la percepción de conocimiento es del $68 \%$.

d. La percepción en cuanto a la conciencia que tiene la comunidad con respecto a la incidencia que el turismo genera sobre la economía es baja, con una calificación de $57 \%$. Por su parte, el $67 \%$ manifiesta que trata al turista con calidez y amabilidad, pero, quizá por la falta de conciencia de la importancia del turismo para el desarrollo local, la percepción del trato que recibe el turista es igualmente baja, pues el $58 \%$ considera que trata al turista como quisiera que fuera tratado.

e. Los encuestados reconocen la amabilidad de los turistas con la comunidad receptora. En este sentido, el $86 \%$ califica al turista como amable y respetuoso; no obstante, los actores del sector turismo que manifestaron sus opiniones concuerdan, en un $74 \%$, con que el desarrollo de la actividad turística produce un conflicto en la comunidad al generarse efectos negativos tales como la drogadicción, robos y prostitución a partir de la afluencia de turistas. 
Figura 9. Evaluación de la cultura turística

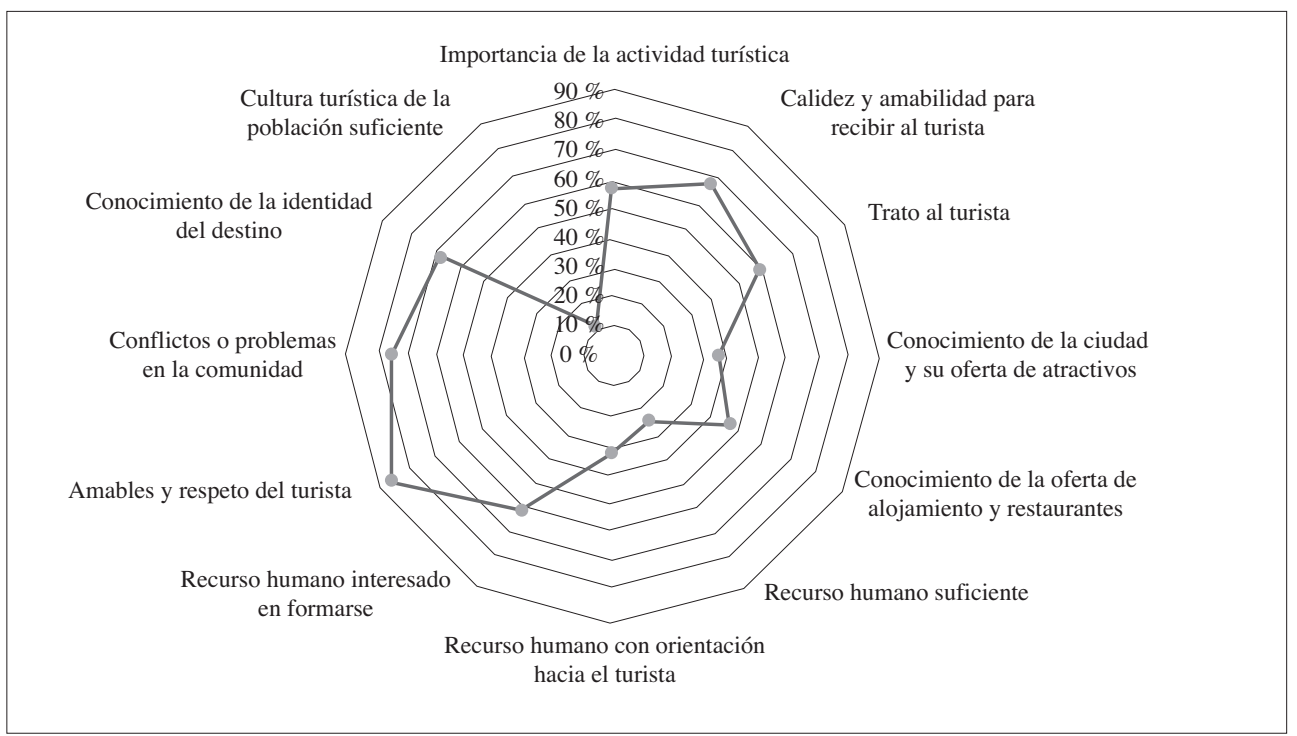

Fuente: Elaboración propia a partir de los datos extraídos de la Unión Temporal de Turismo (2012), 2014

\section{Factores de producción}

\subsection{Cadena de valor}

Con respecto a la cadena de valor, fueron analizadas tanto la interna (propia del sector) como la externa (alianzas con otros sectores económicos).

Es evidente la inexistencia de mecanismos de cooperación entre prestadores de servicios turísticos en cinco de los once departamentos; no obstante, Tolima, Santander y La Guajira reportan porcentajes superiores al $50 \%$, en tanto que los porcentajes de Huila y Bolívar son cercanos al $40 \%$; por su parte, Antioquia concentra sus esfuerzos asociativos y gremiales en su capital, Medellín $(60 \%)$, contrario a los resultados arrojados por las subregiones, que no alcanzan el $10 \%$ (Chocalán, 2012). Las razones aducidas por los entrevistados se refieren a la poca presencia de agentes de viajes operadores que conozcan el quehacer turístico y a la baja preparación de los demás prestadores -ubicados en áreas rurales y municipios- para entender el respeto por los compromisos asumidos. De otra parte, los empresarios entrevistados afirmaron proveerse de insumos agrícolas y papelería en los ámbitos local o regional; los establecimientos de alojamiento y de gastronomía con mejor infraestructura señalaron hacerlo en la capital del país por precio y calidad. No obstante, no se evidencian mecanismos que permitan alianzas más productivas, esto debido precisamente a la poca articulación del sector.

Es preciso adelantar procesos basados en la confianza, que permitan sentar las bases de alianzas prósperas y respetuosas. Existe en las regiones una equivocada percepción de los acuerdos comerciales y las alianzas; asumen que para ello se requiere la constitución de asociaciones y cooperativas, tarea que por demás no es necesaria. 


\subsection{Sistemas gerenciales}

\subsubsection{Uso de tecnologías de la información y la comunicación (TIC)}

La incorporación de TIC en las empresas del sector turístico analizadas fue relativamente baja; en su mayoría manejan software contable y de inventario. El empleo de sistemas de distribución global fue evidente en las agencias de viajes operadoras ubicadas en las capitales departamentales; tan solo el $20 \%$ de los establecimientos de alojamiento cuenta con sistemas de reservas, no obstante, más del $80 \%$ ofrece servicio de Internet a sus clientes. En departamentos como Huila, Tolima y Caldas, los empresarios adujeron falta de recursos económicos para la inversión en tecnologías; si bien un alto porcentaje (más del $90 \%$ ) maneja correo electrónico, no se hace control y seguimiento de este.

Por ser en su mayoría micro y famiempresas con personal empírico (80\%), no creen necesario hacer inversiones tecnológicas; a la mayoría les da temor asumir la responsabilidad de mantener actualizados los procesos sistematizados o que por errores de desconocimiento pierdan la información, por eso prefieren llevarlo en notas escritas, como sucede en el $40 \%$ de los alojamientos de Caldas, Huila y Tolima, y en el $90 \%$ de Nariño.

\subsubsection{Cultura organizacional}

El establecimiento de lineamientos organizacionales es deficiente y precario dentro de las empresas prestadoras de servicios turísticos; tan solo el $29 \%$ ha definido niveles jerárquicos, manuales de funciones, de procedimientos y planeación estratégica (corresponde a establecimientos de alojamiento tipo hoteles con categorías superiores a las tres estrellas y algunas agencias de viajes operadoras de Antioquia, Bolívar y Santander).
El $80 \%$ son microempresas y unidades familiares; por ello, el empirismo en la administración y operación de los establecimientos es alto y presenta inconvenientes para definir su esquema jerárquico; esto impide, además, que se capaciten en aspectos propios de la administración y operación de sus unidades productivas, pues es indudable la concentración de funciones.

\subsubsection{Comportamiento financiero de las empresas}

El $36 \%$ pertenece al régimen común, en consecuencia, han establecido tarifarios y cumplen con sus obligaciones tributarias, acceden a créditos bancarios y de proveedores, y generalmente operan en establecimientos arrendados. Por el contrario, los del régimen simplificado (64\%) son temerosos y desconocedores del sistema financiero, algunos reportan libro de ingresos y gastos sin controles para la toma de decisiones y en su mayoría han iniciado su operación con activos propios.

Los establecimientos de régimen simplificado no cuentan con una estructura tarifaria acorde con sus necesidades; a menor tarifa, mayores son las falencias en manejo adecuado de las finanzas.

\subsubsection{Comercialización y venta por parte de las empresas turísticas}

El mercado al cual dirigen sus servicios no está claramente identificado por parte del conglomerado empresarial turístico; el $36.5 \%$ los ofrece a comerciantes y transportadores de carga pesada; estos no se identifican como prestadores de servicios turísticos. Contrario a ello, los empresarios ubicados en las capitales generalmente dirigen sus esfuerzos al mercado corporativo, pues afirman que los eventos representan cerca del $30 \%$ de sus 
ingresos (establecimientos de alojamiento y hospedaje). En los municipios predominan los grupos familiares en épocas de temporada. Generalmente, hacen uso del Internet a partir de páginas web que se actualizan esporádicamente, limitándose a hacer una descripción básica de los servicios ofrecidos; también emplean material $\mathrm{POP}^{5}$,y muy pocos emplean las redes sociales; predominan el voz a voz y el referido.

Factores que influyen en ello son la falta de confianza para establecer acuerdos, el desconocimiento de la labor de las agencias de viajes como principales comercializadores de los destinos y el empirismo presente en el $80 \%$ de los establecimientos analizados.

\subsubsection{Recurso humano y adopción de esquemas de calidad}

A pesar de la intención de generar procesos de capacitación, no se evidencian avances significativos: tan solo el $30 \%$ cuenta con programas ofrecidos por el Sena. Las políticas de formación del personal están afianzadas en aquellas empresas con sistemas de gestión de calidad, generalmente ubicadas en las capitales departamentales, que solo ascienden al $9 \%$, conformadas en su mayoría por hoteles de categoría; los prestadores turísticos ubicados en los municipios por lo general han instaurado procesos, pero no están documentados.

5 Según la Red Gráfica Latinoamérica, el material Point of Purchase (POP en sus siglas en inglés) "es una categoría del marketing que recurre a la publicidad puesta en los puntos de venta, busca generar una permanencia de la marca recurriendo a una gran variedad de objetos donde se puede imprimir o estampar información de la empresa o producto" (s. f.).
Las deficiencias en la competencia del talento humano constituyen la principal razón de la debilidad operacional y administrativa de las empresas turísticas, aunadas a la falta de liderazgo por parte de autoridades y del sector gremial para emprender procesos que mejoren su productividad.

El Sena juega un papel importante, pues, además de hacer presencia en la mayoría de las regiones, cuenta con una oferta educativa para el sector y es la única institución que certifica en competencias laborales; sin embargo, son procesos que se adelantan en aulas de clase con un mínimo de 25 alumnos, lo que limita la participación de los empleados. No obstante, se resalta la gestión de Cotelco, gremio que a partir de sus programas de capacitación y asesoría técnica ha llevado a varias empresas a la certificación e implantación de sistemas de gestión de calidad, pero lamentablemente esta labor se concentra en las capitales; igual sucede con Acodres y Anato.

\subsection{Calidad de los servicios}

Uno de los mayores logros del sector ha sido la creación de unidades sectoriales de normalización. A la fecha de realización de este trabajo, se contaba con 51 normas técnicas; las variables de calidad que permitieron la caracterización con respecto a planta y servicio se basaron en estándares sectoriales, a saber: 
Tabla 4. Normas técnicas aplicadas en el factor producción

\begin{tabular}{|c|c|c|c|c|}
\hline $\begin{array}{c}\text { Establecimientos } \\
\text { de alojamiento y } \\
\text { hospedaje }\end{array}$ & $\begin{array}{c}\text { Agencias de viajes } \\
\text { operadoras }\end{array}$ & $\begin{array}{c}\text { Establecimientos de } \\
\text { gastronomía }\end{array}$ & Guía de turismo & $\begin{array}{c}\text { Transporte turístico } \\
\text { automotor }\end{array}$ \\
\hline $\begin{array}{l}\text { NTS 006. Requisitos } \\
\text { para una estrella }\end{array}$ & \multirow{2}{*}{$\begin{array}{l}\text { NTS AV 004. Diseño } \\
\text { de paquetes turísticos }\end{array}$} & \multirow{2}{*}{$\begin{array}{l}\text { NTS USNA } 007 . \\
\text { Norma sanitaria de } \\
\text { manipulación de } \\
\text { alimentos }\end{array}$} & \multirow{4}{*}{$\begin{array}{l}\text { Normas por compe- } \\
\text { tencias laborales: } \\
\text { NTS GT } 001 \\
\text { NTS GT } 002 \\
\text { NTS GT } 003 \\
\text { NTS GT } 004\end{array}$} & \multirow{2}{*}{$\begin{array}{l}\text { NTS AV } 009 . \\
\text { Calidad en la pres- } \\
\text { tación del transporte } \\
\text { turístico terrestre } \\
\text { automotor }\end{array}$} \\
\hline $\begin{array}{l}\text { NTS } 007 . \text { Posadas } \\
\text { turísticas }\end{array}$ & & & & \\
\hline $\begin{array}{l}\text { NTS 008. Aloja- } \\
\text { mientos rurales }\end{array}$ & \multirow{2}{*}{$\begin{array}{l}\text { NTS TS 003. Requi- } \\
\text { sitos de sostenibi- } \\
\text { lidad }\end{array}$} & \multirow{2}{*}{$\begin{array}{l}\text { NTS TS } 003 . \text { Requi- } \\
\text { sitos de sostenibi- } \\
\text { lidad }\end{array}$} & & \multirow{2}{*}{$\begin{array}{l}\text { NTS TS } 005 . \text { Requi- } \\
\text { sitos de sostenibi- } \\
\text { lidad }\end{array}$} \\
\hline $\begin{array}{l}\text { NTS TS 002. Requi- } \\
\text { sitos de sostenibi- } \\
\text { lidad }\end{array}$ & & & & \\
\hline
\end{tabular}

Fuente: Elaboración propia a partir de los datos extraídos de la Unión Temporal de Turismo (2012), 2014.

Para el caso de hoteles que contaban con categorización por estrellas superiores a 2, el instrumento no fue aplicado dado que la lista de chequeo se basó en criterios de calidad mínimos, asumiendo que los establecimientos certificados con más estrellas superan estos estándares.

Las normas técnicas sectoriales son desconocidas para la mayoría de los establecimientos turísticos, es así como los requisitos establecidos en la norma de categorización hotelera son cumplidos por un $64 \%$, alcanzando puntajes inferiores al 50\%; las mayores debilidades se presentan en infraestructuras, pues no adelantan mantenimientos preventivos ni control de plagas, y en servicio, al no tener implementados protocolos, en su mayoría no cuentan con programas de contingencia y emergencias. Aquellos ubicados en los municipios, y que ofrecen alimentos y bebidas, desconocen los procesos de inocuidad de los alimentos, de manera que se limitan a gestionar el carné de manipuladores, pero no aplican los conocimientos adquiridos.

Los hoteles ubicados en capitales y que son operados por cadenas reconocidas cumplen los estándares en un rango de entre el 80 y el $100 \%$; sin embargo, son muy pocos los interesados en alcanzar la certificación por estrellas: argumentan que no es necesaria, pues controlan su operación a partir de norma ISO 9001:2008.

Lo contrario ocurre con los alojamientos rurales y las posadas, que alcanzan cumplimientos superiores al $94 \%$; estos hospedajes se ubican en los departamentos de Huila, La Guajira y Caldas; en este último se evidenciaron dos certificados en la NTS TS 002.

Con respecto a los establecimientos de gastronomía, su porcentaje de cumplimiento llega al $60 \%$. Es preciso resaltar que La Guajira y Nariño se encuentran por debajo del promedio nacional, alcanzando el $18 \%$ y $0 \%$, respectivamente. En general, los restaurantes evaluados conocen y aplican buenas prácticas de manufactura; sin embargo, no documentan sus procesos ni hacen estricto control al almacenamiento de las materias primas.

De otra parte, las agencias de viajes, en su mayoría emisivas, alcanzaron el $54 \%$ de cumplimiento y organizan planes del destino cuando los clientes lo solicitan. Llama la atención que si bien la mayoría no diseña paquetes, sí se ha certificado en otras normas sectoriales, referentes a reservas, atención al cliente e infraestructuras. 
Los guías de turismo son generalmente técnicos, conocen su labor, lo que se evidencia en el resultado obtenido: $94 \%$; Norte de Santander y Cundinamarca obtuvieron las calificaciones más bajas, pues cuentan con profesionales sin el debido Registro Nacional de Turismo. Se destacan los guías de Antioquia y La Guajira, con porcentajes superiores al $96 \%$. Nariño y Tolima no fueron seleccionados en la muestra, por lo tanto, no se aplicaron los instrumentos.

El transporte turístico terrestre automotor se analiza en ocho de los once departamentos. Si bien se contemplan en la muestra, no fue posible ubicar las empresas (casos Nariño, Santander y La Guajira). Varios afirmaron no prestar servicios para el turismo, pero tramitaron el Registro Nacional de Turismo por ser transporte especial. De los que prestan servicios turísticos, la mayoría cumple los criterios relacionados con la normativa exigida para su operación; sin embargo, más del $90 \%$ desconoce la norma técnica sectorial.

Por último, se observa la casi nula participación de sector en procesos sostenibles y de responsabilidad social empresarial. Los hoteleros y los alojamientos rurales son los que más aplican criterios de protección al medio ambiente, a la flora y la fauna del lugar. Por su parte, las agencias de viajes conocen y aplican en sus recorridos dichos estándares, pero no así dentro de sus empresas. Los guías de turismo manejan diferentes protocolos para no dejar rastro en sus recorridos e invitan de manera constante al turista a respetar las culturas locales y el medio natural.

\section{Factores de gestión}

\subsection{Gestión de mercadeo}

\subsubsection{Estudio de demanda real}

Como consecuencia del análisis descriptivo realizado en las encuestas de demanda real, se llega a la conclusión de que la nacionalidad preponderante en los destinos turísticos estudiados es la colombiana.A continuación se sintetiza de manera gráfica el perfil del turista real, es decir, el que fue entrevistado en los destinos turísticos más importantes de cada departamento.

Figura 10. Perfil de la demanda real

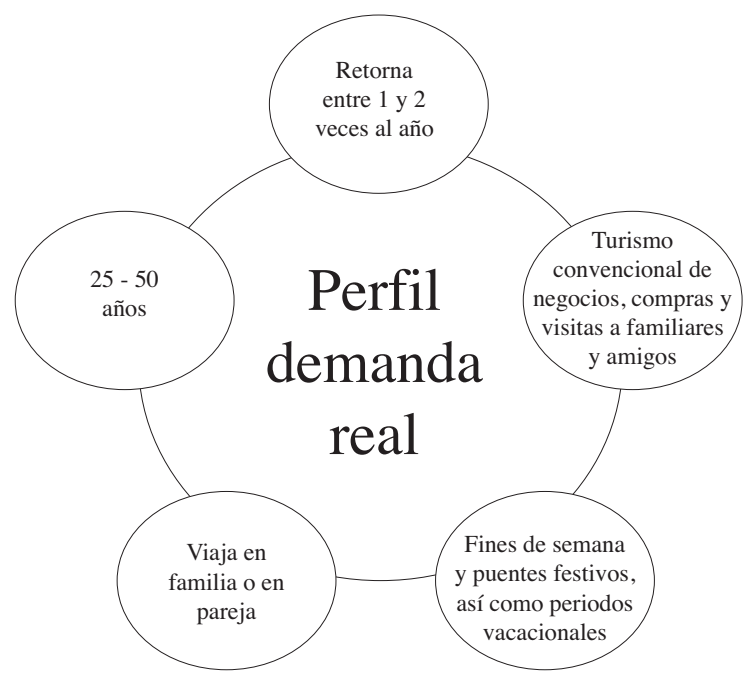

Fuente: Unión Temporal de Turismo, 2012. 
Aunque la directriz es clara en la mayoría de los departamentos, es importante destacar que en Cundinamarca y Norte de Santander el turista dice retornar al destino entre tres y cinco veces al año, en el caso de Cundinamarca, por la cercanía a la capital de la república. Además, en los departamentos de Caldas y Norte de Santander existe una tendencia a que el turista viaje de manera individual. Únicamente en Valle del Cauca y Antioquia el rango de edad de los turistas desciende a los 18-35 años. Para terminar con las excepciones al perfil de la demanda real, se recalca que los turistas que visitan los departamentos de Nariño y Valle del Cauca aluden motivos religiosos a la hora de elegir su destino.

Es un buen momento para destacar variables cualitativas que arrojan datos sugestivos sobre las características de los destinos. Así, el $97,1 \%$ de los entrevistados regresaría a los lugares donde se encontraban por varios motivos, entre los más importantes están el buen ambiente $^{6}$ (con 75,8\% de las respuestas más repetidas), seguido de los negocios $(10,4 \%)$ y la familia $(9,6 \%)$. Vale la pena resaltar el interés de los encuestados por la impronta histórico-cultural de algunos destinos turísticos del país, como los municipios pertenecientes a la Red Pueblos Patrimonio de Colombia, la cual fue percibida por los turistas en un número significativo de respuestas $(4,2 \%)$.

Cuando se preguntó a los turistas encuestados por los aspectos negativos de los destinos que se encontraban visitando, la mayoría concordó con que la accesibilidad-movilidad era deficiente, que todavía existían problemas de seguridad y que la contaminación era evidente. También recalcaron aspectos como el desaseo, aspectos sociales (focos de pobreza), falta de información y señalización.

6 Los entrevistados relacionan "buen ambiente" con clima agradable, calidez, amabilidad y hospitalidad de la comunidad local, belleza del destino turístico y/o de sus atractivos, así como la tranquilidad que se respira durante su estadía.
Al indagar por las actividades no ofrecidas por el destino y que les gustaría encontrar, se priorizaron cuatro: esparcimiento, deportivas y recreativas, culturales y recorridos turísticos, de manera que se constata que en la gestión del destino no se está articulando la vocación de este ni las necesidades del público objetivo a la oferta de actividades. En este sentido, en departamentos que no tienen vocación principal de turismo de aventura (Antioquia, Bolívar, Huila, La Guajira, Nariño y Valle del Cauca), los turistas desean encontrar actividades relacionadas con esta tipología. Por otro lado, en Nariño, Valle del Cauca, La Guajira, Huila, Norte de Santander y Bolívar, se desea encontrar actividades relacionadas con el ecoturismo.

\subsubsection{Estudio de demanda potencial}

En cuanto al perfil de la demanda potencial, se puede afirmar que la mayoría es de género femenino, entre 20 y 45 años, perteneciente a los estratos 1 y 4 , con un nivel de formación de secundaria y, por lo general, empleado asalariado (Cundisán, 2012, p. 343).

Los destinos más visitados por la demanda potencial se localizan en lugares ubicados en zonas de playa: Cartagena con $26,1 \%$ y Santa Marta con $25,9 \%$, tendencia totalmente concordante con la motivación principal de los turistas encuestados, dado que "el 53,3\%, sobre una base de 1381 respuestas prefiere salir de vacaciones en búsqueda de un lugar de descanso con la familia, mientras que el $18,1 \%$ lo hace por actividades recreativas" (Chocalán, 2012, p. 392).

Otros de los destinos turísticos preferidos por la demanda potencial a la hora de tomar sus vacaciones son los urbanos, que se llevan un $22,7 \%$ del pastel: Bogotá $(12,6 \%)$ y Medellín $(10,1 \%)$. Finalmente, se encuentra la isla de San Andrés, con 9,6\%, reincidiendo con la motivación de descanso. Como destino emer- 
gente para la demanda potencial se posiciona el Eje Cafetero, con 6,1\%.

Al preguntar a los encuestados por los destinos turísticos que quisieran visitar en los próximos cinco años, las respuestas no variaron demasiado. Se destacan en el más alto nivel cinco: San Andrés isla, Cartagena, Eje Cafetero, Santa Marta y Medellín.

Los colombianos encuestados manifestaron alojarse varios días en los destinos de su preferencia, siendo más de 5 noches el periodo más frecuente $(45,7 \%)$, mientras que el $39,2 \%$ se aloja entre 3 y 5 noches, y únicamente el $15 \%$ pernocta en el destino entre 1 y 2 noches. (Chocalán, 2012,p. 393).

El transporte público terrestre es el mayormente utilizado por la demanda potencial, con $55,4 \%$, así como el vehículo particular, con $26,6 \%$, mientras que solo el $14,5 \%$ dijo movilizarse en avión.

Los colombianos encuestados prefieren destinos en los cuales puedan realizar actividades relacionadas con el turismo de sol y playa, acompañados principalmente de sus familias o pareja. En cuanto a las fechas o periodos, es evidente una fuerte tendencia a viajar durante las vacaciones, demandando principalmente el medio de transporte público terrestre o utilizando el vehículo particular. (Chocalán, 2012, p. 395).

Empero, "existe una demanda creciente para desplazarse a lugares con una vocación natural fuerte, tales como la Amazonía (27,7\%), y por destinos turísticos con vocación históricocultural (26,8\%)" (Chocalán, 2012, p. 397).

Los canales de información y compra para la muestra encuestada son directamente los prestadores de servicios turísticos; en menor proporción están las agencias de viajes. Internet no inspira todavía confianza, a pesar de que ha cobrado relevancia en los últimos años (Chocalán, 2012).

\subsubsection{Posicionamiento del destino: imagen corporativa e institucional}

El $80 \%$ de los departamentos analizados cuenta con sitios web y material promocional turístico institucional. La información turística que se maneja en el caso del contenido on line es más bien descriptiva e informativa por medio de guías, directorios, rutas, entre otros recursos que no permiten que el visitante interactúe con el sitio. La presencia institucional turística en redes sociales a nivel departamental o ciudad capital no es fuerte; en ocasiones la información se encuentra desactualizada y no se desarrolla contenido turístico, dando prioridad a información institucional genérica. Pese a lo anterior, se aprecia que algunos municipios tienen en cuenta las redes sociales en su estrategia de promoción, contando con perfiles institucionales en redes como Facebook, Twitter, Linkedin o Flirck.

Todos los departamentos tienen presencia en guías de viaje nacionales como Viaja por $\mathrm{Co}$ lombia, Colombia.travel (Proexport), Guía de turismo verde, Guía de rutas por Colombia y Posadas turísticas. En cuanto a la presencia en guías internacionales, la mayoría de los departamentos tiene presencia con atractivos muy puntuales y ciudades capitales, siendo las más representativas Petit FutéTravel Guide, Lonely Planet y Viva Travel Guide; algunos tienen presencia en el motor de opiniones Tripadvisor.

En general, se puede decir que el posicionamiento institucional está más orientado hacia la promoción de las capitales departamentales, resaltando atractivos culturales como centros históricos, monumentos y festivales. Dependiendo de la vocación de cada departamento, se enfatiza en la promoción de unos atractivos, pero no de otros. No obstante, de- 
partamentos como La Guajira promocionan ampliamente sus municipios más importantes, en detrimento de la capital. Al contrastar lo anterior con la existencia de una imagen de marca departamental o marca ciudad, se descubre que solo la mitad de los departamentos tiene una marca departamental definida y bien estructurada, mientras que aproximadamente el $67 \%$ cuenta con marca ciudad.

\subsection{Gestión turística}

A continuación se analizan las relaciones existentes entre actores estratégicos por medio de las siguientes fórmulas extraídas del formato de relación de actores:

Empresarios - recursos humanos. Se encuentran falencias en las condiciones laborales del empleado vinculado al sector turístico, incluso en lo referido al marco laboral, al cual no se le da cumplimiento. La formación o capacitación continua del recurso humano sigue teniendo poca importancia para los gerentes de establecimientos turísticos de los departamentos estudiados. Las respuestas en cuanto a incorporación de mano de obra local están bastante divididas, aunque se evidencia una tendencia al alza a la hora de incorporar personas locales en la actividad turística; sucede lo mismo con el desarrollo y mejoramiento de la capacidad empresarial.

Empresarios - comunidad local. La participación de la comunidad local en las decisiones estratégicas y de gestión del destinos turísticos es baja, su injerencia es nula y presenta una baja incidencia en las decisiones sobre el desarrollo del destino turístico. La responsabilidad social corporativa y la participación del empresario-empresa en eventos sociales, culturales y ambientales no son aspectos notables.

Empresarios - administración local - gremios. Se vislumbra una tendencia departa- mental en cuanto a la mejoría del grado de eficacia de la gestión de la administración local y del sector privado en materia de turismo, aunque el grado de formulación de proyectos conjuntos es todavía incipiente al respecto. Existen datos esperanzadores en cuanto al nivel de trabajo conjunto en las esferas público-privadas para la promoción de los destinos.

Administración - comunidad local. Existe una debilidad general en cuanto a los programas de sensibilización, información y cultura turística dirigidos a los residentes, por lo que la comunidad local en muchas ocasiones es ajena a la importancia de la actividad turística; por ende, su participación es casi inexistente.

Destino - Gobierno nacional. El grado de coordinación entre ambos actores es plausible, pero no se evidencian acciones significativas en la planificación y gestión de destino, ni en la dotación de infraestructuras según las necesidades de la demanda.

Destino - turistas. Se evidencian en esta relación algunos síntomas ocasionados por la categoría anterior, porque los encuestados estiman que los destinos todavía no están preparados para la llegada de turistas, de manera que no se están enfocando $100 \%$ en sus necesidades: los atractivos turísticos no están puestos en valor, la calidad de las infraestructuras es mejorable, no existe información del destino, falta de señalización turística, la relación calidad-precio todavía no es justa y no existe una medición de incidencias que garantice el disfrute en la experiencia global del turista.

Destino - competidores. De manera general, en los departamentos se tiene la sensación de contar con buenos productos turísticos en comparación con la competencia; sin embargo, esta percepción es empírica, porque el destino no tiene información sobre los competidores, es decir, no se han desarro- 
llado estudios técnicos ni formales sobre la actividad que están realizando los destinos turísticos competidores regionales, nacionales o internacionales.

Destino - operadores y/o mayoristas. La capacidad de negociación con mayoristas y/u operadores externos es baja, por lo que su grado de dependencia no es considerable.El número de operadores de los departamentos no es alto; hay una tendencia de concentración en las ciudades capitales, pero la participación regional, es decir, en áreas rurales, es muy baja, casi inexistente. Por otro lado, se evidencia una falta de claridad en cuanto a las funciones que debe realizar una agencia de viajes y turismo, una mayorista o una operadora, de manera que existe conflicto entre los diferentes roles que marca el Decreto 502 de 1997, que estipula las tipologías y las funciones de las agencias de viajes en Colombia.

\section{Resultados}

Los resultados de la investigación adelantada en el marco de la planificación turística en los departamentos estudiados se consideran de triple vía: en primer lugar, se sintetiza el resultado del instrumento DOFA aplicado por factor en cada departamento, mediante el cual se ponen de manifiesto las fortalezas, debilidades, oportunidades y amenazas más importantes ${ }^{7}$. Posteriormente, el anexo 7 presenta la georreferenciación de los atractivos priorizados en cada departamento, en la cual se demuestra la alta concentración en los clústeres, microclústeres, rutas y circuitos, frente a un porcentaje significativo del territorio que no cuenta con vocación turística, dado que esta es muy focalizada. En último lugar, se presentan a continuación los proyectos prioritarios que son tendencia en el planteamiento y desarrollo de la fase estratégica de cada uno de los planes de desarrollo turístico: 


\section{Tabla 5. Proyectos estratégicos por factor}

\begin{tabular}{|c|c|c|}
\hline Factor & & Proyectos estratégicos \\
\hline \multirow{6}{*}{ Atracción } & \multicolumn{2}{|c|}{$\begin{array}{l}\text { Diseño y estructuración de productos turísticos especializados }{ }^{5} \text {, innovadores, competitivos y que incorporen } \\
\text { de manera transversal criterios de sostenibilidad: avistamiento de aves, ballenas, naturaleza, rutas ambientales, } \\
\text { ecoturismo, cultura, turismo rural, aventura, eventos y congresos, parques temáticos con identidad local, ocio- } \\
\text { recreación y bienestar, entre otros. }\end{array}$} \\
\hline & \multicolumn{2}{|c|}{$\begin{array}{l}\text { Puesta en valor de la diversidad gastronómica regional y local, los valores artesanales y musicales, las ferias y } \\
\text { fiestas, para su integración en el producto turístico de cada zona. }\end{array}$} \\
\hline & \multicolumn{2}{|c|}{$\begin{array}{l}\text { Elaboración e implementación de estudios técnicos para ordenamiento, gestión y manejo de la oferta natural y } \\
\text { cultural con base en criterios de sustentabilidad. }\end{array}$} \\
\hline & \multicolumn{2}{|c|}{$\begin{array}{l}\text { Definición e implementación de actividades experienciales según productos y creación de clubes de productos } \\
\text { especializados. }\end{array}$} \\
\hline & \multicolumn{2}{|c|}{$\begin{array}{l}\text { Fortalecimiento, consolidación y mejoramiento de la calidad de ofertas complementarias al producto turístico: } \\
\text { museos, parques temáticos, sitios de interés natural, etc. }\end{array}$} \\
\hline & \multicolumn{2}{|c|}{$\begin{array}{l}\text { Diseño y gestión de productos y rutas turísticas multidestino a nivel nacional, y en algunos casos, en alianza con } \\
\text { destinos internacionales que se complementan por vocación. }\end{array}$} \\
\hline \multirow{4}{*}{ Producción } & \multicolumn{2}{|c|}{ Consolidación del tejido empresarial. } \\
\hline & \multicolumn{2}{|c|}{ Impulso a la incorporación de estándares de calidad y sostenibilidad en la prestación de servicios. } \\
\hline & \multicolumn{2}{|c|}{ Fortalecimiento del trabajo asociado entre empresarios. } \\
\hline & \multicolumn{2}{|c|}{ Formación y asistencia técnica a los empresarios. } \\
\hline \multirow{15}{*}{ Soporte } & \multirow{2}{*}{ Espacio público } & Mejoramiento del amueblamiento urbano en los municipios con vocación turística. \\
\hline & & Recuperación y embellecimiento de espacio público para el turismo. \\
\hline & \multirow{3}{*}{$\begin{array}{l}\text { Ordenamiento } \\
\text { territorial y } \\
\text { planificación } \\
\text { integral }\end{array}$} & $\begin{array}{l}\text { Articulación del planeamiento turístico con la planificación y el ordenamiento territorial } \\
\text { (planes, planes básicos y esquemas de ordenamientos territoriales municipales y planes). }\end{array}$ \\
\hline & & $\begin{array}{l}\text { Apoyo a municipios en reglamentación y manejo de aprovechamiento económico del espa- } \\
\text { cio público, incluidas ventas informales. }\end{array}$ \\
\hline & & Asistencia técnica para la incorporación del componente turístico en los POT municipales. \\
\hline & \multirow{4}{*}{$\begin{array}{l}\text { Conectividad vial } \\
\text { para el turismo }\end{array}$} & Recuperación y mantenimiento de las principales vías para el turismo. \\
\hline & & $\begin{array}{l}\text { Gestión para el fortalecimiento de las condiciones de conectividad terrestre a sitios de } \\
\text { interés turístico y atractivos. }\end{array}$ \\
\hline & & Plan de señalización turística vial, peatonal e interpretativa. \\
\hline & & Construcción de terminales terrestres en municipios que no cuentan con tal infraestructura. \\
\hline & \multirow{2}{*}{$\begin{array}{l}\text { Señalización } \\
\text { turística }\end{array}$} & $\begin{array}{l}\text { Mejoramiento de la señalización vial y turística en los clústeres, microclústeres, rutas y } \\
\text { circuitos identificados. }\end{array}$ \\
\hline & & Mantenimiento de la señalización actual. \\
\hline & \multirow{3}{*}{$\begin{array}{l}\text { Conectividad } \\
\text { digital y acceso a la } \\
\text { información }\end{array}$} & Ampliación de la cobertura de Internet y de telefonía móvil en los destinos para el turismo. \\
\hline & & Creación y puesta en marcha de observatorios turísticos en los departamentos. \\
\hline & & Fortalecimiento del plan Vive Digital. \\
\hline & $\begin{array}{l}\text { Cultura turística y } \\
\text { sensibilización }\end{array}$ & $\begin{array}{l}\text { Sensibilización turística a la comunidad receptora, instituciones educativas, entidades y } \\
\text { organismos relacionados con el turismo de los clústeres, microclústeres, rutas y circuitos } \\
\text { identificados. }\end{array}$ \\
\hline \multirow{13}{*}{ Gestión } & \multirow{8}{*}{$\begin{array}{l}\text { Gestión de } \\
\text { mercadeo }\end{array}$} & $\begin{array}{l}\text { Fortalecimiento o replanteamiento de las marcas turísticas en el ámbito territorial-depar- } \\
\text { tamental. }\end{array}$ \\
\hline & & $\begin{array}{l}\text { Diseño del material promocional para cada departamento, que incluya las marcas turísticas } \\
\text { fortalecidas o replanteadas, acorde con la vocación turística de las regiones y sus productos } \\
\text { turísticos. }\end{array}$ \\
\hline & & Desarrollo de aplicaciones turísticas para dispositivos móviles. \\
\hline & & $\begin{array}{l}\text { Creación de portales turísticos donde se unifiquen los productos y destinos de los departa- } \\
\text { mentos, o rediseño de los sitios web que estén en mejores condiciones. }\end{array}$ \\
\hline & & Articulación de redes sociales en la promoción de cada departamento. \\
\hline & & $\begin{array}{l}\text { Realización de viajes de familiarización con mayoristas y agencias de viajes nacionales y } \\
\text { con tour operadores internacionales. }\end{array}$ \\
\hline & & Viajes de reconocimiento para periodistas. \\
\hline & & Diseño y ejecución de campañas promocionales. \\
\hline & \multirow{5}{*}{ Gestión turística } & $\begin{array}{l}\text { Fortalecimiento institucional a partir de la reestructuración de oficinas de turismo, grupos } \\
\text { de turismo, sea cual sea la nomenclatura sobre la cual trabajan los funcionarios en los } \\
\text { temas relacionados con el turismo. }\end{array}$ \\
\hline & & Fortalecimiento de los comités departamentales de turismo. \\
\hline & & Creación de comités subregionales y municipales de turismo. \\
\hline & & Creación o mejora de sistemas de información turística departamental. \\
\hline & & $\begin{array}{l}\text { Fortalecimiento de la gestión público-privada y la cooperación entre los diferentes actores } \\
\text { estratégicos. }\end{array}$ \\
\hline
\end{tabular}

Fuente: Elaboración propia a partir de los datos extraídos de la Unión Temporal de Turismo (2012), 2014. 
Posterior a la fase estratégica, se formularon 33 perfiles de proyecto "prioritarios" en total, tres para cada departamento. Además, se articuló una etapa de evaluación, seguimiento y control de cada uno de los planes por medio de una propuesta de indicadores.

\section{Conclusiones}

Los desarrollos teóricos en cuanto a la conceptualización de la competitividad turística ponen de manifiesto como denominador común la necesidad de generar una visión de futuro del sector, al momento de concebir una política de planificación y de desarrollo turístico. Por tanto, no basta con describir o enumerar cada uno de los factores con incidencia en el desarrollo de la industria; es necesario articularlos al macroentorno político que está orientado al mejoramiento de las condiciones del territorio, entendiendo el turismo como una actividad altamente estructurada y vinculada con diversos sectores de la economía, con los cuales interactúa generando incidencias directas e indirectas.

Es necesario, desde la planificación del sector, abandonar la concepción de la competitividad como un elemento estático, para visualizarlo como uno dinámico en el cual las ventajas competitivas se ganan o se pierden, según la estrategia trazada, haciendo necesario planear el sostenimiento de los factores diferenciadores ya existentes y el mejoramiento de aquellos en los cuales se evidencian dificultades. Para lograr lo anterior, es importante considerar los estudios diagnósticos realizados sobre los destinos, con los cuales se logren desarrollar políticas para el sector que aborden de manera eficiente la situación actual y planteen acciones estratégicas para hacer frente a los nuevos desafíos a partir de un enfoque competitivo.

Tal como se evidencia a partir de las diferentes disertaciones de los teóricos de la com- petitividad turística, es clara la necesidad de integrar soluciones, políticas y estrategias desde una perspectiva interdisciplinaria y multidimensional. No es posible entender hoy en día el turismo como una actividad aislada; por el contrario, debe ser comprendida como un factor fundamental en el desarrollo de una economía, lo cual demanda la participación activa de toda la sociedad y los aportes desde las diferentes ramas de la ciencia que puedan coadyuvar en el mejoramiento de las potencialidades de un destino, y con ello su posicionamiento competitivo.

Los enfoques conceptuales y metodológicos planteados en el marco teórico no distan mucho entre sí; por el contrario, permiten establecer un conjunto de elementos comunes, tales como aquellos relacionados con las condiciones del destino, los aspectos del entorno que facilitan su disfrute, entre otros. Sin embargo, es necesario seguir el estudio de las dinámicas competitivas del sector a niveles aún más específicos, es decir, en la ciudad e incluso en relación con los diferentes actores de la cadena de valor.

Respecto a los cuatro factores de competitividad, se concluye lo siguiente: en las áreas rurales el factor atracción presenta condiciones que dificultan el acceso, bien sea por falta de aeropuertos, vías terrestres en adecuadas condiciones o por el grado de dificultad para llegar a algunas zonas apartadas. Si bien en ciertas zonas de las áreas analizadas hay una oferta artesanal de alta calidad, en algunos casos no es representativa de valores culturales locales, puesto que prevalecen productos importados y de baja factura. Por lo anterior, es clave impulsar el eje de sustentabilidad para el destino y para los prestadores de servicios turísticos, dado que se presentan problemas de contaminación auditiva, visual, por generación de residuos, no planificación de áreas naturales, falta de medición de capacidad de carga, control a visitantes en zonas de alta vulnerabilidad ambiental y cultural, entre 
otros.Además, se evidencia el deterioro urbanístico en algunos centros históricos, así como una transformación de valores históricos y culturales que ponen en riesgo la identidad cultural. Es responsabilidad del sector turístico asumir un compromiso en el cuidado del patrimonio natural y cultural, considerado el principal motivador de desplazamientos; empero, los resultados son desalentadores, pues en su mayoría no conocen, entienden ni están interesados en adoptar políticas hacia la sostenibilidad.

Con respecto a áreas de alto valor paisajístico y natural, cabe destacar que cuentan con un acceso restringido debido a problemas estructurales de orden público y seguridad, lo que redunda en la no viabilidad de visita a corto plazo, sumado al hecho de que todavía se tiene una mala imagen del lugar, lo que afecta la decisión del viaje, dando como resultado un aislamiento simbólico y real del destino.

La concentración de los atractivos está focalizada en áreas concretas de cada departamento, por lo que se puede afirmar que solamente una parte del territorio nacional es turística, real o potencial, frente a territorios que realmente no tenían vocación turística en el momento del estudio.

El conglomerado empresarial turístico presenta una amplia brecha productiva y competitiva, basada en el empirismo, que conlleva a la falta de conocimiento de la regulación turística y al poco interés por generar procesos de capacitación continua tanto en lo operativo como en lo administrativo; desconocen por completo las ventajas y los incentivos ofrecidos por el Gobierno nacional para su fortalecimiento.

Al no conocer el quehacer turístico ni entender que este se consolida a partir de las alianzas estratégicas y de la identificación de los roles y responsabilidades de cada uno de los subsectores, los empresarios ubicados en áreas rurales y municipios actúan individualmente, no creen en la labor comercial de las agencias de viajes, asumen que ellas disminuyen sus ingresos al cobrar comisión y, por supuesto, no saben diseñar tarifarios basados en estructuras de costos.

Preocupa el hecho de que $36 \%$ de los empresarios tipo alojamiento analizados sean hospedajes dirigidos a mercados de transporte de carga y por horas, los cuales cuentan con Registro Nacional de Turismo activo.

La concentración de empresarios mejor establecidos y con altos índices de calidad y sostenibilidad en la prestación de sus servicios se ubica en las capitales departamentales, esto debido a que es allí donde hacen presencia los gremios turísticos que establecen programas de capacitación específicos.

En los destinos turísticos abundan los turistas nacionales por encima de los internacionales, segmento todavía incipiente, aunque en constante incremento según datos aportados por entidades como el Viceministerio de Turismo o Proexport (2014).

En lo que respecta al factor de soporte, es clara la existencia -en los ámbitos departamental y nacional- de un marco normativo y regulatorio suficiente para organizar la actividad turística; sin embargo, es necesario materializar este marco en una planificación que desarrolle la vocación turística que tiene cada departamento desde un enfoque de competitividad. En tal sentido, los planes de desarrollo turístico establecen una base diagnóstica para emprender acciones estratégicas que permitan posicionar los destinos a nivel mundial, atrayendo un adecuado flujo de turistas, sin dejar de lado la conservación y preservación de los atractivos.

Para lograr esta potenciación de los destinos, el país avanza en la construcción de una infraestructura, tanto en términos de conectivi- 
dad como de acceso a los servicios esenciales. Este desarrollo debe llegar a todos los departamentos y ha de permitir el mejoramiento de las vías para la conectividad terrestre, la construcción y adecuación de aeropuertos y el mejoramiento de la red de servicios públicos, con óptimos niveles de acceso y calidad.

El avance en la seguridad es notorio y se refleja en la disminución de atentados, secuestros, entre otros, empero es necesario avanzar en la consolidación de una política de seguridad ciudadana y de manejo de los problemas de esta índole en los centros urbanos.

Se debe seguir trabajando en la consolidación de una cultura turística, de tal manera que la comunidad adquiera conciencia del turismo como actividad que puede promover su desarrollo económico, que la incentive a mejorar la calidad de atención al turista y que genere procesos de apropiación que conlleven a acciones que mejoren su experiencia. El desarrollo del recurso humano, en cuanto a formación y capacitación, es primordial en el mejoramiento de esta cultura turística, de tal forma que el talento humano adquiera las competencias necesarias para brindar un buen servicio.

En relación con el factor de gestión, en general se puede afirmar que la imagen de los destinos turísticos se ve influida negativamente por aspectos como el desaseo, los focos de pobreza y la contaminación.

Los destinos no están ofreciendo las actividades turísticas que los turistas esperan encontrar, por lo que no se cumple con sus expectativas de viaje. Hay una tendencia clara a querer encontrar actividades relacionadas con la cultura, la recreación, el esparcimiento, el deporte, el ecoturismo y el turismo de aventura. Los recorridos turísticos siguen siendo muy importantes para la demanda real.

Los destinos de sol y playa (Cartagena, Santa Marta y San Andrés, preferentemente) son los más visitados o los más deseados por la demanda potencial a la hora de viajar, siendo la motivación principal el descanso con la familia. No obstante, destinos urbanos como Bogotá o Medellín siguen siendo importantes, dado su posicionamiento nacional e internacional. El Eje Cafetero se cataloga como un destino emergente por destacar. Los colombianos entrevistados se informan y compran sus vacaciones de manera autónoma, lo hacen por cuenta propia y no por medio de agencias de viajes o Internet, sobre todo los que se movilizan en vehículo particular o transporte público, que son la mayoría.

Es conveniente ajustar el enfoque promocional de cada departamento, dado que el actual no corresponde a las realidades turísticas; es decir, se tienen en cuenta atractivos que no existen o permanecen cerrados o en mal estado, etc. (Huitonava, 2012). Con base en lo anterior, los destinos deben propender por ofrecer a los mercados una información turística veraz para llegar a su público objetivo. Casi todos los departamentos contaban, en el momento del estudio, con una promoción turística institucional suficiente, a excepción de Valle del Cauca y Nariño, donde se detectó un vacío considerable en ese particular. Desde la perspectiva de redes sociales, se deben generar esfuerzos por aumentar la visibilidad institucional, contando con información turística oportuna y actualizada. Así mismo, es hora de dar un mayor protagonismo a las áreas rurales, pues se tiene como epicentro las capitales, adonde está llegando el turista. La presencia en guías nacionales es justa, pero se puede mejorar lo relacionado con guías internacionales.

Las relaciones entre los actores del sector son afables, pero todavía se evidencia un trabajo descoordinado y desarticulado, en ocasiones dirigido a proyectos que no son tan relevantes o prioritarios para el desarrollo y/o gestión de los destinos turísticos. Se refleja la necesidad de crear estrategias para que las empresas 
desplieguen programas de formación y capacitación para sus empleados, condición sine qua non para el fomento de la excelencia y la calidad del servicio turístico. El papel de la comunidad local en la gestión y planificación turística es todavía incipiente, siendo necesario sensibilizar y capacitar a este importante actor con el objetivo de fomentar su participación en los procesos estratégicos del sector para concebir destinos turísticos a la medida de la población que los habita y de los turistas que los visita. Se considera una prioridad estudiar a los competidores de los destinos turísticos colombianos, tanto dentro como fuera del país, dado que es la única forma de marcar pautas de diferenciación e innovación; para ello, hay que estructurar y diseñar productos especializados acordes con las vocaciones de los territorios. Es necesario que cada destino turístico busque cuál es su fórmula de gestión turística ideal y que afiance los lazos entre los diferentes actores que en él participan.

En los destinos turísticos se pueden destacar fortalezas, como la presencia de atractivos naturales y culturales, algunos catalogados como patrimonio de la humanidad por la UNESCO, así como su posicionamiento y reconocimiento en la mente del turista. En cuanto a la asignatura pendiente, debe ser preeminente la adecuación de los destinos y de sus productos a las necesidades de la demanda real y potencial, con base en criterios de sostenibilidad.

Alrededor de los destinos estudiados hay oportunidades como el marco legal y normativo que rige la actividad turística, las certificaciones de sostenibilidad en todos sus niveles, el aprovechamiento de ventajas competitivas que ofrece el reconocimiento de las ciudades capitales como foco atractivo de turistas o las declaratorias UNESCO, para fortalecer la llegada a destinos rurales, menos conocidos por los turistas. Como amenazas más evidentes están las relacionadas con el arribo de turistas a los destinos: fenómenos como la aculturación y la masificación, proliferación de destinos competidores y la percepción de inseguridad en algunos de los destinos turísticos del interior.

Chocó es uno de los departamentos con mayores ventajas para el desarrollo del turismo de naturaleza y el ecoturismo, concentrado en la región del Urabá Caribe, en los municipios de Nuquí y Bahía Solano, cercanos al Parque Nacional Natural Utría y, por supuesto, en su capital Quibdó; requiere de fuertes procesos de acompañamiento técnico para lograr una distribución equitativa de los recursos generados por el turismo, teniendo en cuenta dos aspectos fundamentales: que la Ley 70 de 1993 reconoce el derecho a la propiedad colectiva de la tierra para las comunidades afrocolombianas que ocupan zonas rurales baldías ubicadas en las riberas de los ríos de la cuenca del Pacífico, y que Colombia adoptó el Convenio n. ${ }^{\circ} 169$ de 1989 de la OIT sobre Pueblos Indígenas y Tribales ${ }^{8}$; lamentablemente, este proceso no se llevó a cabo por parte del Fondo de Promoción Turística, lo que ocasionó el rechazo de algunos líderes locales y, en consecuencia, la paralización del trabajo. La carta de navegación del destino habría sido fundamental para afrontar las actividades que hoy se adelantan en el territorio, como el arribo de cruceristas, la declaratoria de ser el mejor destino ecoturístico del mundo -otorgada a Colombia en la Feria Turística de Sanghai 2014-, las inversiones en infraestructura turística adelantadas por el Fondo Nacional de Turismo y el enorme potencial para gestionar el turismo comunitario en procura de la mejora de la calidad de vida de sus habitantes. Si bien los beneficios de

\footnotetext{
8 La consulta previa, entendida como la participación de estos "en todas las decisiones susceptibles de afectarlas directa o indirectamente, hace hincapié en el derecho inherente de todo ser humano a ser consultado previamente a la toma de decisiones que le puedan afectar su modo de vida, sus creencias, sus tierras y territorios y a participar, cuando sea posible, de los beneficios que se derivan de ciertos proyectos de desarrollo" (Ministerio del Interior y de Justicia, 2009, p. 12).
} 
la consulta previa procuran la inclusión y la igualdad de los grupos étnicos, los tiempos requeridos para adelantarla superan el destinado para la formulación del plan turístico. Se espera, entonces, que el Ministerio de Comercio, Industria y Turismo coordine los asuntos inherentes a dicho procedimiento y se logre, en un futuro cercano, la consolidación del plan turístico chocoano.

\section{Bibliografía}

Alonso, V. (2010). Factores críticos de éxito y evaluación de la competitividad de destinos turísticos. Estudios y Perspectivas en Turismo, 19(2), 201-220. Recuperado de http://goo.gl/DSQpoE

Ávila, R.y Barrado,D. (2005). Nuevas tendencias en el desarrollo de los destinos turísticos: marcos conceptuales y operativos para su planificación y gestión. Cuadernos de Turismo, 15, 27-44. Recuperado de http://goo.gl/EyKkbT

BOLINORSAGUA, U. T. (2012). Plan de desarrollo turístico de Bolívar 2012-2015. Bogotá D.C.: FONTUR.

CHOCALÁN, U. T. (2012). Plan de desarrollo turístico de Antioquia, 2012-2015. Bogotá D.C.: FONTUR.

Mazars Turismo y Corporación Andina de Fomento (CAF). (2003). Proyecto de mejora del sector turismo en la Comunidad Andina. Recuperado de http://goo.gl/x4aIEh

Crouch, G. I., \& Ritchie, J. R. B. (1999). Tourism, competitiveness and societal prosperity. Journal of Business Research, 44(3), 137-152.

Crouch, G. (2011). Destination competitiveness: An analysis of determinant attributes. Journal of Travel Research, 49(3), 27- 45. Recuperado de http://goo.gl/qUnvHK
CUNDISÁN, U. T. (2012). Plan de desarrollo turístico de Santander 2012-2015. Bogotá D.C.: FONTUR.

Dwyer, L., \& Kim, C. (2003). Destination Competitiveness: Determinants and Indicators. Current Issues in Tourism, 6(5), 369-414. Recuperado de http://goo.gl/xOJw5y

González, R. C. y Mendieta, M. D. (2009). Reflexiones sobre la conceptualización de la competitividad de destinos turísticos. Cuadernos de Turismo 23, 111-128. Recuperado de http://goo. $\mathrm{gl} / \mathrm{PkToqK}$

Hassan, S. (2000). Determinants of market competitiveness in an environmentally sustainable tourism industry. Journal of travel research, 38(3), 239-245. Recuperado de http://goo.gl/uxg9q9.

HUITONAVA, U. T. (2012). Plan de desarrollo turístico del Tolima 2012-2015. Bogotá D.C.: FONTUR.

Jiménez, O. y Cavazos, J. (2012). El turismo orientado a los pobres: una alternativa estratégica para los países en desarrollo. Revista de Turismo y Patrimonio Cultural, 10(5), 451-465. Recuperado de http://goo.gl/cyTC20

Khin, E., Daengbuppha, J., \& Nonsiri, P. (2014). Destination competitiveness: a structural model for measuring attributes competitiveness of Bagan, Myanmar. International Journal of Business, Economics and Law, 4(2), 51-59. Recuperado de http://goo.gl/E93uYy

Klytchnikova, I., \& Dorosh, P. (agosto de 2013). Tourism sector in Panamá: regional economic impacts and the potential to benefit the poor (n. 6183). Policy Research Working Paper. Recuperado de http://goo.gl/HBmonV

Mara, R., \& Varzin, G. (2008). Modelos de competitividad para los destinos turísticos en el marco de la sostenibilidad. Revista de Administração 
Contemporânea, 12(3), 789-809. Recuperado de http://goo.gl/dYHlyJ

Melisidou, S., Papageorgiou, A., Papayiannis, D., \& Varvaressos, S. (septiembre de 2014). Tourism cluster as a potentially effective tool for local development and sustainability. Trabajo presentado en la $4^{\text {th }}$ Internacional Conference on Tourism y Hospitality Management, Roma, 218-230.

Ministerio de Comercio, Industria y Turismo. (s. f.). Asistencia técnica en planificación del turismo. Recuperado de http://goo.gl/0E2Brb

Mireno Rodríguez, R. y Pulido Fernández, J. I. (2009). Desarrollo turístico y dinámica relacional: metodología de análisis para la gestión activa de destinos turísticos. Cuadernos de Turismo, 23, 173-193. Recuperado de http://goo.gl/arjXrn

Mireno, R. y Zamora, E. (2009). La colaboración entre los actores turísticos en ciudades patrimoniales. Reflexiones para el análisis del desarrollo turístico. Pasos. Revista de Recuperado de Turismo y Patrimonio Cultural, 7(2), 219-238. Recuperado de http://goo.gl/ZPo3ir

Organización Mundial del Turismo (OMT). (14 de mayo de 2014). El turismo internacional genera 1,4 billones en ingresos derivados de exportaciones (PR14034). Comunicado de prensa de la OMT. Recuperado de http://goo.gl/0AQKLW

Osorio, M. (2006). La planificación turística: enfoques y modelos. Quivera. Revista de estudios urbanos, regionales, territoriales, ambientales y sociales, 8(1), 291-314. Recuperado de http:// goo.gl/B169ua
Pascarrella, R., \& Fontes, J. (2010). Competitividad de los destinos turísticos: modelos de evaluación basados en las capacidades dinámicas y sus implicaciones en las políticas públicas. Estudios y Perspectivas en Turismo, 19, 1-17. Recuperado de http://goo.gl/7c7Pci

Porter,M. (2007). La ventaja competitiva de las naciones. Harvard Business Review América Latina. Recuperado de http://goo.gl/Lezibc

Quintero, P., Bernal, C. y López, H. (2005). La competitividad turística de Cartagena de Indias: análisis del destino y posicionamiento en el mercado. Serie de Estudios sobre la Competitividad de Cartagena n. ${ }^{\circ} 4$. Recuperado de http://goo.gl/ HDPijA

Red Gráfica Latinoamérica. (s.f.). El material POP y su utilidad. Recuperado de http://goo.gl/zBMphl

Ritchie, B., \& Crouch, G. (2010). A model of destination competitiveness/sustainability: Brazilian perspectives. Revista de Administração Pública, 44(5), 1049-1066. Recuperado de http://goo.gl/ Fbte4B

Sánchez, M. y Fajardo, M. (28 de mayo de 2004). La competitividad de los destinos turísticos: un análisis cuantitativo mediante modelos logísticos. Aplicación a los municipios extremeños. Trabajo presentado en I Jornada de Economía del Turismo, Palma de Mallorca. Recuperado de http://goo.gl/ EfUp9T.

Unión Temporal del Turismo. (2012). Planes de desarrollo turístico departamental 2012-2015. Bogotá, D.C.: FONTUR. 


\section{Anexos}

Anexo 1. Metodología e instrumentos de recolección de datos por factor de análisis

\begin{tabular}{|c|c|c|}
\hline Factor & Metodología & Instrumentos \\
\hline \multirow{5}{*}{ Soporte } & \multirow{5}{*}{$\begin{array}{ll}\text { - } & \text { Análisis y síntesis de fuentes secundarias. } \\
- & \text { Observación de campo, entrevistas en profundi- } \\
& \text { dad para valoración de infraestructuras y seguri- } \\
& \text { dad según destino. } \\
- & \text { Valoración de componentes de ordenamiento } \\
& \text { territorial según fuentes secundarias. } \\
-\quad & \text { Visita de campo para valoración de impactos } \\
& \text { ambientales y proyectos con impacto territorial. }\end{array}$} & $\begin{array}{l}\text { Formato de observación de campo para valoración de in- } \\
\text { fraestructuras en términos de calidad: muelles, malecones, } \\
\text { aeropuertos. }\end{array}$ \\
\hline & & $\begin{array}{l}\text { Formato de entrevistas en profundidad a expertos en infraes- } \\
\text { tructuras y seguridad. }\end{array}$ \\
\hline & & $\begin{array}{l}\text { Visita de campo para valoración ambiental y de componen- } \\
\text { tes territoriales. }\end{array}$ \\
\hline & & Análisis de la cultura turística. \\
\hline & & Análisis de fuentes secundarias. \\
\hline \multirow{7}{*}{ Atracción } & \multirow{7}{*}{$\begin{array}{l}\text { - Análisis y revisión de fuentes primarias y } \\
\text { secundarias. } \\
\text { - Utilización de formatos varios para el recaudo } \\
\text { de la información. } \\
\text { - Visitas de campo para valoración de clúster, } \\
\text { microclúster, rutas y circuitos turísticos. }\end{array}$} & $\begin{array}{l}\text { Taller de socialización de la propuesta de formulación del } \\
\text { plan. }\end{array}$ \\
\hline & & Formato para validación y selección de atractivos. \\
\hline & & Formatos de valoración de atractivos para visita de campo. \\
\hline & & $\begin{array}{l}\text { Formato de análisis de paquetes por departamento. } \\
\text { Recolección de fuentes secundarias. }\end{array}$ \\
\hline & & Formato con matriz de criterios para valoración de atractivos. \\
\hline & & Selección de clúster, microclúster, rutas y circuitos. \\
\hline & & Taller de validación de clúster, microclúster, rutas y circuitos. \\
\hline \multirow[b]{2}{*}{ Producción } & \multirow{2}{*}{$\begin{array}{l}\text { - Análisis de información secundaria. } \\
\text { - Visitas a una muestra de empresarios identifica- } \\
\text { dos en la cadena de valor de las zonas turísticas } \\
\text { en cada departamento, a partir de una matriz de } \\
\text { valoración de la calidad con criterios de competi- } \\
\text { tividad y sostenibilidad. }\end{array}$} & $\begin{array}{l}\text { Formato de entrevista en profundidad para entidades de } \\
\text { formación. }\end{array}$ \\
\hline & & $\begin{array}{l}\text { Lista de chequeo de calidad, sostenibilidad y criterios de } \\
\text { competitividad empresarial. }\end{array}$ \\
\hline \multirow{3}{*}{ Gestión } & \multirow{3}{*}{$\begin{array}{l}\text { - Revisión de fuentes secundarias. } \\
\text { - Valoración de niveles de coordinación y gestión } \\
\text { interinstitucional público-privada. } \\
\text { - Revisión de fuentes secundarias para identifi- } \\
\text { cación de canales de distribución, niveles de } \\
\text { precio, etc. } \\
\text { - Valoración de productos potenciales para colo- } \\
\text { car en el mercado futuro. } \\
\text { - Investigación de mercados de la demanda actual } \\
\text { y potencial en el ámbito nacional. }\end{array}$} & Formato relaciones actores. \\
\hline & & $\begin{array}{l}\text { Aplicación de sondeo a demanda actual y encuesta a deman- } \\
\text { da potencial. }\end{array}$ \\
\hline & & Mapa de actores estratégicos. \\
\hline \multirow{2}{*}{$\begin{array}{l}\text { Síntesis del } \\
\text { diagnóstico } \\
\text { DOFA. Cons- } \\
\text { trucción de } \\
\text { visión }\end{array}$} & \multirow{2}{*}{$\begin{array}{l}\text { Análisis de información de fuentes secundarias, } \\
\text { talleres y consolidación de informes del equipo. }\end{array}$} & $\begin{array}{l}\text { Taller de presentación de síntesis de diagnóstico y validación } \\
\text { de DOFA. }\end{array}$ \\
\hline & & Taller de construcción de visión y lluvia de ideas de estrategias. \\
\hline \multirow{2}{*}{$\begin{array}{l}\text { Formulación } \\
\text { estratégica: } \\
\text { matriz de } \\
\text { marco lógico }\end{array}$} & \multirow{2}{*}{ Trabajo de escritorio } & Taller de validación de estrategias. \\
\hline & & Taller de presentación de plan final. \\
\hline
\end{tabular}

Fuente: Unión Temporal de Turismo, 2012. 


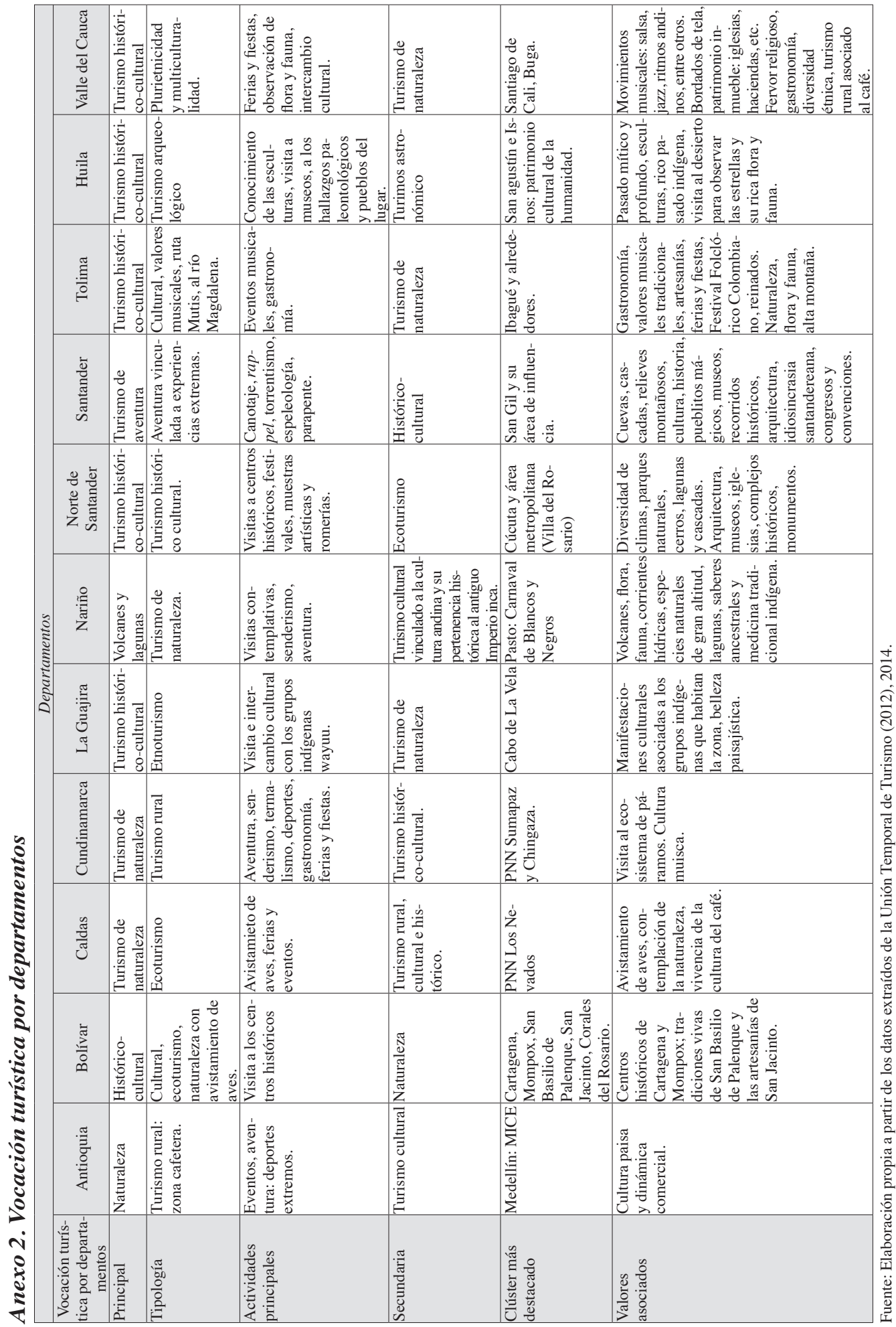

Rev. Turismo y Sociedad, vol. xvı, enero-junio 2015, pp. 131-185 


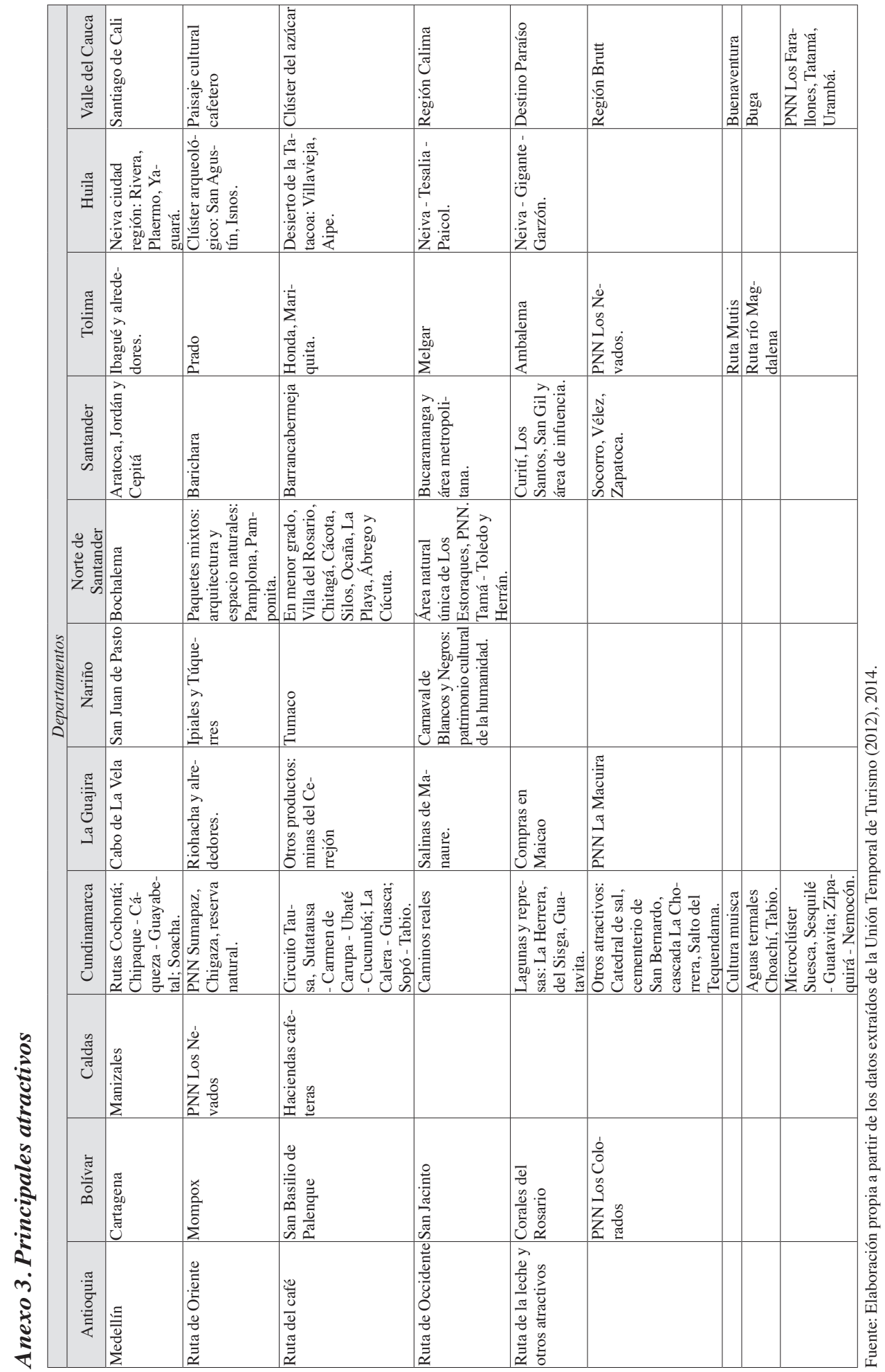

Rev. Anuario Turismo y Sociedad, vol. xvi, enero-junio 2015, pp. 131-185 


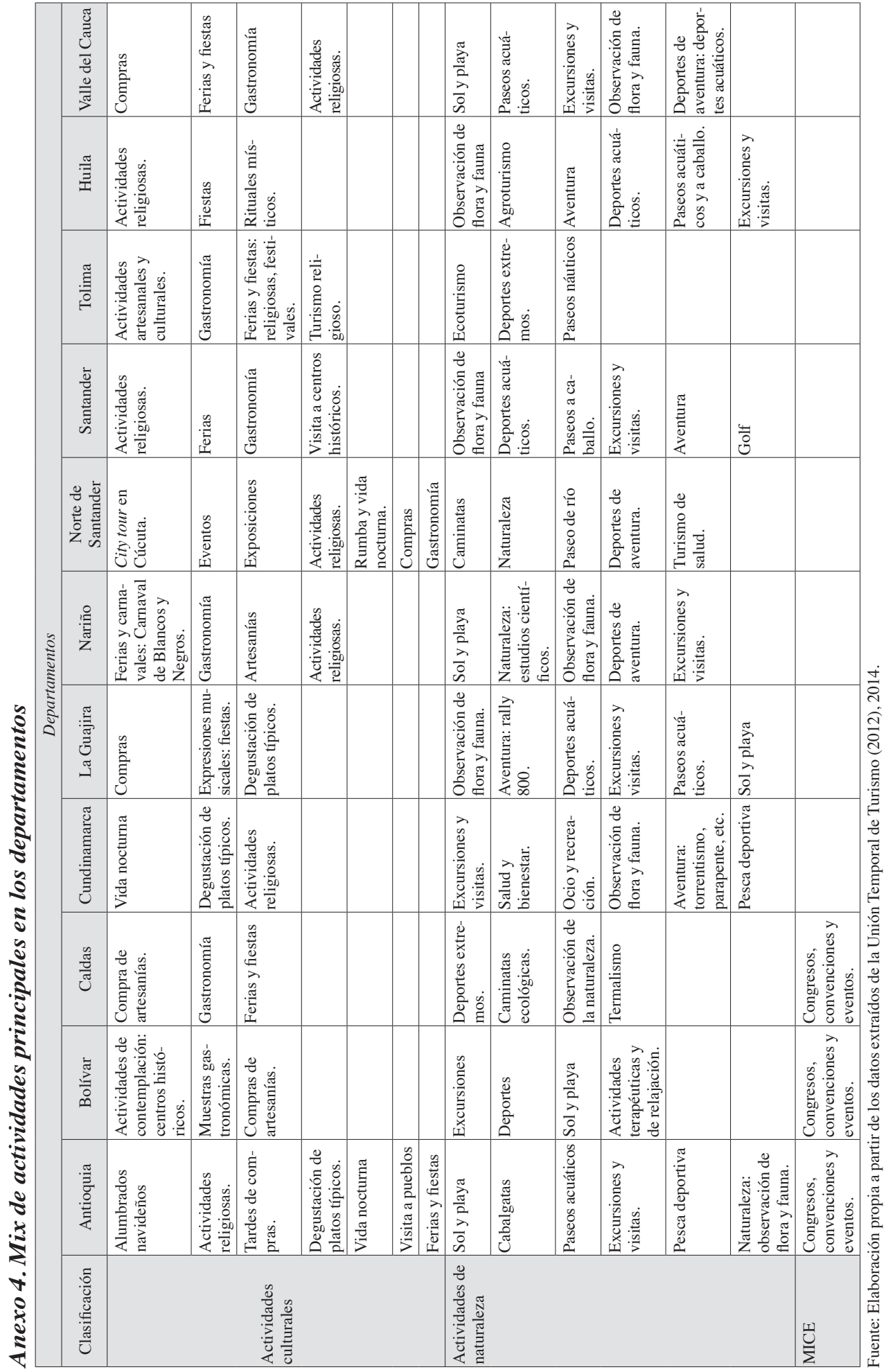

Rev. Turismo y Sociedad, vol. xvı, enero-junio 2015, pp. 131-185 


\section{Anexo 5. Síntesis marco regulatorio para los once planes de desarrollo turísticos departamentales}

La Constitución Política de Colombia de 1991 crea los lineamientos generales para ubicar el turismo como una opción para los colombianos. En los artículos 8, 44, 52, 63, $72,79,80,95$ y 300 se consignan contenidos relacionados con el turismo, desde la obligación que tienen los ciudadanos en lo que respecta a la protección de las riquezas naturales y culturales, pasando por la responsabilidad de la nación en la protección de los bienes de uso público, el patrimonio arqueológico y los diferentes bienes culturales que confirman la identidad nacional, hasta las disposiciones que habilitan a los entes departamentales para expedir disposiciones para la planeación y el desarrollo económico y social del turismo.

En cuanto a leyes, se encuentra la Ley 300 de 1996, modificada por la Ley 1101 de 2006 y por la Ley 1558 de 2012. La Ley 300, también conocida como Ley General de Turismo, regula la actividad a partir de nueve principios: "concertación, coordinación, descentralización, planeación, protección al ambiente, desarrollo social, libertad de empresa, protección al consumidor y fomento; incorpora aspectos de relevancia para el desarrollo del turismo, como descentralización de las funciones, planeación del sector, turismo de interés social, el mercadeo del sector, la promoción y la cooperación internacional, los prestadores de servicios turísticos y algunas disposiciones finales" (CHOCOLÁN, 2012, p. 30).

Por su parte, la Ley 1101 de 2006 se desarrolla con el objetivo de "adquirir mayores recursos para la promoción y competitividad del sector, por medio de la contribución parafiscal y su destinación al turismo como inversión social, propone dentro de sus lineamientos aumentar la base de contribuyentes de ese pago y recaudar un impuesto a los turistas extranjeros; igualmente reglamenta el uso de los recursos y la administración del Fondo de Promoción Turística" (CHOCOLÁN, 2012, p. 31).

A continuación se listan otras normativas relacionadas con el sector turismo, a partir de los marcos regulatorios de los once planes de desarrollo turístico:

1. Ley 768 de 2002, por la cual se adopta el régimen político, administrativo y fiscal de los distritos Portuario e Industrial de Barranquilla, Turístico y Cultural de Cartagena de Indias y Turístico, Cultural e Histórico de Santa Marta.

2. Ley 788 de 2002, por la cual se establecen exenciones del impuesto de renta y complementarios a los servicios hoteleros y al servicio de ecoturismo.

3. Ley 1185 de 2008. Establece el Régimen Especial de Protección de los Bienes de Interés Cultural.

4. Ley $\mathbf{1 3 3 6}$ de 2009, por medio del cual se adiciona y robustece la Ley 679 de 2001 de lucha contra la explotación, la pornografía y abuso sexual con niños, niñas y adolescentes.

5. CONPES 3110. Establece la política para el desarrollo del turismo náutico.

6. CONPES 3397. Conocido como el Conpes de Turismo. Contiene los lineamientos para el desarrollo integral del sector en el país partiendo de un diagnóstico general.

7. CONPES 3640. Contiene los lineamientos de política para el desarrollo del turismo de convenciones y congresos.

8. CONPES 3658. Establece los lineamientos de política para la recuperación de los centros históricos. 
9. Política de mercadeo y promoción turística de Colombia. Sus ejes temáticos se orientan hacia la diferenciación de estrategias en los mercados nacionales e internacionales, así como en la articulación necesaria en los ámbitos de formulación y aplicación de las estrategias de mercadeo y promoción desde las instituciones nacionales responsables.

10. Política para el desarrollo del ecoturismo. Busca fortalecer y diversificar la actividad ecoturística en el país teniendo como referente esencial su desarrollo sostenible.

\section{Política de turismo cultural: "Identidad} y desarrollo competitivo del patrimonio". Busca posicionar a Colombia como un destino de turismo cultural, nacional e internacional, que mediante el aprovechamiento de su diversidad y riqueza cultural genere dinámicas de desarrollo local y cadenas productivas sostenibles que promuevan la competitividad del patrimonio y la identidad de las regiones.

12. Política de turismo y artesanías, que promueve iniciativas conjuntas para el impulso y la promoción del patrimonio artesanal y el turismo colombiano; tiene como principal objetivo integrar, como propuesta de desarrollo conjunto, sostenible y responsable, las cadenas productivas de los sectores turismo y artesanía.
13.Política de turismo social, la cual pretende facilitar el acceso de todos los colombianos al turismo, como una posibilidad real para el ejercicio del derecho fundamental a la recreación y aprovechamiento del tiempo libre, otorgando prioridad a aquellos segmentos de población con menores posibilidades de su disfrute, tales como las personas con discapacidad, las personas mayores, los jóvenes y las personas de escasos recursos económicos.

14. Política de calidad turística, encaminada a mejorar la prestación de los servicios turísticos que se ofrecen en el mercado, el fortalecimiento de los destinos turísticos y de las empresas prestadoras de servicios turísticos en la gestión de calidad, como una estrategia clara para generar la cultura de excelencia que permita posicionar a Colombia como un destino turístico de calidad, diferenciado y competitivo en los mercados turísticos del mundo.

\section{Plan Sectorial de Turismo: "Turismo:} factor de prosperidad para Colombia" 2011-2014. Tiene como objetivo fundamental mejorar la competitividad de los servicios y destinos turísticos de Colombia con el fin de hacer del turismo una estrategia de desarrollo sostenible para el país. 
Anexo 6. Síntesis DOFA por factores (tendencia nacional)

\begin{tabular}{|c|c|c|c|}
\hline \multicolumn{4}{|c|}{ Factores de atracción } \\
\hline Fortalezas & Debilidades & Oportunidades & Amenazas \\
\hline \multirow{4}{*}{$\begin{array}{l}\text { Gran diversidad natural y } \\
\text { cultural, de ecosistemas, } \\
\text { de flora, fauna y climas. }\end{array}$} & $\begin{array}{l}\text { Contaminación de resi- } \\
\text { duos, auditiva, visual, } \\
\text { atmosférica, por vertimien- } \\
\text { tos en varios destinos del } \\
\text { país, que afectan la oferta } \\
\text { de atractivos naturales y } \\
\text { culturales. }\end{array}$ & \multirow{4}{*}{$\begin{array}{l}\text { Priorización del producto } \\
\text { de turismo de naturaleza } \\
\text { y turismo de salud en el } \\
\text { ámbito nacional. }\end{array}$} & $\begin{array}{l}\text { Baja implementación de } \\
\text { planes especiales de mane- } \\
\text { jo y protección de centros } \\
\text { históricos y riesgos aso- } \\
\text { ciados a no cumplimiento } \\
\text { de planes de ordenamiento } \\
\text { territorial. }\end{array}$ \\
\hline & $\begin{array}{l}\text { Deficientes servicios de } \\
\text { guía e interpretación am- } \\
\text { biental y cultural en varias } \\
\text { zonas del país. Bajo nivel } \\
\text { de bilingüismo. }\end{array}$ & & $\begin{array}{l}\text { Problemas de infraestruc- } \\
\text { tura vial y accesibilidad a } \\
\text { los atractivos. }\end{array}$ \\
\hline & $\begin{array}{l}\text { Falta de conciencia am- } \\
\text { biental de prestadores y } \\
\text { visitantes. }\end{array}$ & & $\begin{array}{l}\text { Continuo deterioro del } \\
\text { hábitat }^{*} \text {. }\end{array}$ \\
\hline & $\begin{array}{l}\text { Problemas de conserva- } \\
\text { ción de atractivos naturales } \\
\text { y culturales. Deterioro } \\
\text { urbanístico en algunos } \\
\text { centros históricos. }\end{array}$ & & $\begin{array}{l}\text { Deterioro de ecosistemas } \\
\text { derivado de actividades } \\
\text { productivas no controladas } \\
\text { (minería, etc.). }\end{array}$ \\
\hline $\begin{array}{l}\text { Existencia de normas } \\
\text { técnicas sectoriales en } \\
\text { turismo sostenible }\end{array}$ & & $\begin{array}{l}\text { Existencia de instrumentos } \\
\text { de política sectorial: eco- } \\
\text { turismo, turismo cultural, } \\
\text { turismo comunitario, entre } \\
\text { otros. }\end{array}$ & $\begin{array}{l}\text { Deterioro de ecosistemas } \\
\text { derivado de actividades } \\
\text { productivas no contro- } \\
\text { ladas. }\end{array}$ \\
\hline $\begin{array}{l}\text { Diversidad gastronómica } \\
\text { regional }\end{array}$ & & $\begin{array}{l}\text { Fortalecimiento institu- } \\
\text { cional y de recursos para } \\
\text { turismo nacional. }\end{array}$ & \\
\hline $\begin{array}{l}\text { Declaratorias de bienes de } \\
\text { interés cultural de nivel } \\
\text { nacional y como patrimo- } \\
\text { nio de la humanidad; y de } \\
\text { áreas protegidas del nivel } \\
\text { nacional, regional, munici- } \\
\text { pal y reservas privadas. }\end{array}$ & $\begin{array}{l}\text { Deficiencia en estudios } \\
\text { técnicos relacionados con } \\
\text { capacidad de carga, planes } \\
\text { de manejo en algunas áreas } \\
\text { protegidas, entre otros. }\end{array}$ & $\begin{array}{l}\text { Diversidad de fuentes de } \\
\text { financiamiento. }\end{array}$ & \\
\hline
\end{tabular}

* Deforestación, ampliación de la frontera agropecuaria, cacería, entre otros.

Fuente: Elaboración propia a partir de la información recogida en los planes de desarrollo turístico departamentales, 2014. 


\begin{tabular}{|c|c|c|c|}
\hline \multicolumn{4}{|c|}{ Factores de soporte } \\
\hline Fortalezas & Debilidades & Oportunidades & Amenazas \\
\hline \multirow{3}{*}{$\begin{array}{l}\text { Programas de recuperación } \\
\text { del espacio público. }\end{array}$} & $\begin{array}{l}\text { Limitado y poco espacio } \\
\text { público para habitantes, } \\
\text { turistas y visitantes. }\end{array}$ & $\begin{array}{l}\text { Recuperación de zonas pa- } \\
\text { ra la generación de espacio } \\
\text { público. }\end{array}$ & $\begin{array}{l}\text { Transformación del paisaje } \\
\text { inmediato mediante culti- } \\
\text { vos y edificaciones. }\end{array}$ \\
\hline & $\begin{array}{l}\text { Aumento de la invasión } \\
\text { del espacio público. }\end{array}$ & $\begin{array}{l}\text { La cercana revisión de los } \\
\text { POT en el país permite ha- } \\
\text { cer ajustes para superar los } \\
\text { problemas del sector. }\end{array}$ & $\begin{array}{l}\text { Descoordinación entre la } \\
\text { planificación sectorial y el } \\
\text { ordenamiento territorial. }\end{array}$ \\
\hline & $\begin{array}{l}\text { Deficiente señalización } \\
\text { vial y turística. Adecua- } \\
\text { ción de los servicios de } \\
\text { apoyo e infraestructura en } \\
\text { algunos atractivos. }\end{array}$ & & \\
\hline $\begin{array}{l}\text { Convenio para la ejecución } \\
\text { del programa "Colombia } \\
\text { Vive Digital". }\end{array}$ & $\begin{array}{l}\text { Bajo uso de TIC en la pro- } \\
\text { moción de los destinos. }\end{array}$ & \multirow{3}{*}{$\begin{array}{l}\text { Nuevos proyectos de in- } \\
\text { versión en infraestructura a } \\
\text { nivel del Gobierno central. }\end{array}$} & \multirow{3}{*}{$\begin{array}{l}\text { Muy baja creatividad, } \\
\text { innovación y utilización de } \\
\text { la tecnología aplicada. }\end{array}$} \\
\hline \multirow[t]{2}{*}{$\begin{array}{l}\text { Buena cobertura de tele- } \\
\text { fonía móvil e Internet en } \\
\text { áreas urbanas. }\end{array}$} & $\begin{array}{l}\text { Señal deficiente en algunas } \\
\text { zonas de los departamen- } \\
\text { tos, especialmente en el } \\
\text { área rural. }\end{array}$ & & \\
\hline & $\begin{array}{l}\text { Falta de cobertura en redes } \\
\text { de banda ancha. }\end{array}$ & & \\
\hline $\begin{array}{l}\text { Buena infraestructura y } \\
\text { cobertura de los servicios } \\
\text { de energía eléctrica. }\end{array}$ & $\begin{array}{l}\text { Bajo nivel de cobertura de } \\
\text { servicios de alcantarillado } \\
\text { y acueducto. }\end{array}$ & & \\
\hline \multirow{4}{*}{$\begin{array}{l}\text { Presencia de la fuerza } \\
\text { pública }\end{array}$} & $\begin{array}{l}\text { Bajo conocimiento de los } \\
\text { atractivos turísticos por } \\
\text { parte de la fuerza pública. }\end{array}$ & \multirow[t]{4}{*}{$\begin{array}{l}\text { Aumento del flujo de turis- } \\
\text { tas gracias a la seguridad } \\
\text { en los departamentos. }\end{array}$} & \\
\hline & $\begin{array}{l}\text { Percepción de inseguridad } \\
\text { en algunas áreas. }\end{array}$ & & \\
\hline & $\begin{array}{l}\text { Falta participación activa } \\
\text { de los municipios en el } \\
\text { Consejo de Seguridad } \\
\text { Turística, para su forta- } \\
\text { lecimiento y gestión más } \\
\text { efectiva. }\end{array}$ & & \\
\hline & $\begin{array}{l}\text { Baja articulación interins- } \\
\text { titucional con la Policía de } \\
\text { Turismo. }\end{array}$ & & \\
\hline \multirow[b]{2}{*}{$\begin{array}{l}\text { Buen estado de la red vial } \\
\text { primaria }\end{array}$} & $\begin{array}{l}\text { Red vial secundaria y } \\
\text { terciaria en condiciones no } \\
\text { óptimas. }\end{array}$ & & \\
\hline & $\begin{array}{l}\text { Concentración vial en tor- } \\
\text { no a las capitales o grandes } \\
\text { ciudades, pero muy débil } \\
\text { en el resto de los muni- } \\
\text { cipios. }\end{array}$ & & \\
\hline
\end{tabular}




\begin{tabular}{|c|c|c|c|}
\hline \multicolumn{4}{|c|}{ Factores de soporte } \\
\hline Fortalezas & Debilidades & Oportunidades & Amenazas \\
\hline \multirow{5}{*}{$\begin{array}{l}\text { Buen comportamiento de } \\
\text { los indicadores económi- } \\
\text { cos en el ámbito regional. }\end{array}$} & & $\begin{array}{l}\text { Lineamientos y políticas } \\
\text { nacionales que favorecen } \\
\text { el medio ambiente. }\end{array}$ & \multirow{5}{*}{$\begin{array}{l}\text { Espacios para la competi- } \\
\text { tividad }^{* *} \text {. }\end{array}$} \\
\hline & & $\begin{array}{l}\text { Tendencia al ecoturismo } \\
\text { sustentable que ayude a la } \\
\text { vigilancia y conservación. }\end{array}$ & \\
\hline & & $\begin{array}{l}\text { Existencia de la política de } \\
\text { turismo comunitario. }\end{array}$ & \\
\hline & & $\begin{array}{l}\text { Incentivos económicos } \\
\text { para el ecoturismo. }\end{array}$ & \\
\hline & $\begin{array}{l}\text { Aumento de la economía } \\
\text { informal. }\end{array}$ & $\begin{array}{l}\text { Crecimiento y estabilidad } \\
\text { económica del país. }\end{array}$ & \\
\hline $\begin{array}{l}\text { Existencia de servicios de } \\
\text { salud en la mayoría de los } \\
\text { municipios con vocación y } \\
\text { demanda turística. }\end{array}$ & $\begin{array}{l}\text { Concentración de servicios } \\
\text { de salud de alta comple- } \\
\text { jidad en las capitales o } \\
\text { grandes ciudades. }\end{array}$ & & \\
\hline \multirow{2}{*}{$\begin{array}{l}\text { La búsqueda de alternati- } \\
\text { vas productivas propicia } \\
\text { la disposición al cambio y } \\
\text { una receptividad del local } \\
\text { hacia el turismo. }\end{array}$} & \multirow{2}{*}{$\begin{array}{l}\text { No hay continuidad de } \\
\text { los procesos de proyectos } \\
\text { que soportan la actividad } \\
\text { turística. }\end{array}$} & & $\begin{array}{l}\text { Posibilidades de desarrollo } \\
\text { de bloques subregionales } \\
\text { de integración productiva. }\end{array}$ \\
\hline & & & $\begin{array}{l}\text { No consolidar la oferta tu- } \\
\text { rística local y los procesos } \\
\text { comunitarios asociados } \\
\text { en mercados regionales y } \\
\text { nacionales. }\end{array}$ \\
\hline & $\begin{array}{l}\text { Migración de la pobla- } \\
\text { ción del área rural al área } \\
\text { urbana. }\end{array}$ & & $\begin{array}{l}\text { Pérdida de la identidad } \\
\text { histórico-cultural. }\end{array}$ \\
\hline & & & $\begin{array}{l}\text { Descomposición social } \\
\text { como efecto del turismo } \\
\text { mal planificado. }\end{array}$ \\
\hline & & & $\begin{array}{l}\text { Problemas de pobreza que } \\
\text { afectan seriamente a las } \\
\text { comunidades locales en di- } \\
\text { ferentes destinos del país. }\end{array}$ \\
\hline
\end{tabular}

Fuente: Elaboración propia a partir de la información recogida en los planes de desarrollo turístico departamentales, 2014. 


\begin{tabular}{|c|c|c|c|}
\hline \multicolumn{4}{|c|}{ Factores de producción } \\
\hline Fortalezas & Debilidades & Oportunidades & Amenazas \\
\hline $\begin{array}{l}\text { Se proveen casi en su } \\
\text { mayoría con empresas } \\
\text { locales. }\end{array}$ & $\begin{array}{l}\text { No existen alianzas estra- } \\
\text { tégicas que conlleven a } \\
\text { fortalecer la cadena interna } \\
\text { de valor. }\end{array}$ & $\begin{array}{l}\text { Alianzas con la academia } \\
\text { y/o gobernaciones para } \\
\text { capacitaciones. }\end{array}$ & $\begin{array}{l}\text { Pocas relaciones comer- } \\
\text { ciales con otros sectores } \\
\text { económicos. }\end{array}$ \\
\hline $\begin{array}{l}\text { Uso de las TIC para fines } \\
\text { contables y de inventario. }\end{array}$ & $\begin{array}{l}\text { El comportamiento fi- } \\
\text { nanciero de la mayoría de } \\
\text { las empresas turísticas se } \\
\text { caracteriza por pertenecer } \\
\text { al régimen simplificado } \\
\text { (negocios familiares), sin } \\
\text { mayor conocimiento del } \\
\text { sector. }\end{array}$ & $\begin{array}{l}\text { Presencia del Sena con } \\
\text { programas de formación } \\
\text { en turismo. }\end{array}$ & $\begin{array}{l}\text { Concentración de empre- } \\
\text { sas turísticas con sistemas } \\
\text { de gestión de calidad } \\
\text { y procesos sostenibles } \\
\text { adecuados en las capitales } \\
\text { departamentales. }\end{array}$ \\
\hline $\begin{array}{l}\text { Inversión con capital } \\
\text { propio. }\end{array}$ & $\begin{array}{l}\text { Son pocos los que cuentan } \\
\text { con una estructura organi- } \\
\text { zacional. }\end{array}$ & $\begin{array}{l}\text { Programas institucionales } \\
\text { que conllevan el uso de } \\
\text { tecnologías. }\end{array}$ & $\begin{array}{l}\text { Falta de recursos para } \\
\text { incorporar TIC en las } \\
\text { microempresas y a las em- } \\
\text { presas familiares. }\end{array}$ \\
\hline \multirow[t]{3}{*}{$\begin{array}{l}\text { Presencia gremial turística } \\
\text { en capitales departamen- } \\
\text { tales. }\end{array}$} & $\begin{array}{l}\text { Personal no competente } \\
\text { para la labor que desem- } \\
\text { peña. }\end{array}$ & $\begin{array}{l}\text { Existencia de recursos en } \\
\text { el Fondo de Promoción } \\
\text { Turística para certificar } \\
\text { prestadores turísticos en } \\
\text { NTS y cualificar el talento } \\
\text { humano. }\end{array}$ & $\begin{array}{l}\text { Presencia de estableci- } \\
\text { mientos informales que } \\
\text { generan competencia } \\
\text { desleal. }\end{array}$ \\
\hline & $\begin{array}{l}\text { Desconocimiento de } \\
\text { esquemas de calidad sec- } \\
\text { toriales y desinterés por } \\
\text { adoptarlos. }\end{array}$ & $\begin{array}{l}\text { Existencia de fondos del } \\
\text { Gobierno nacional para } \\
\text { mejorar la competitividad } \\
\text { de las empresas turísticas. }\end{array}$ & $\begin{array}{l}\text { Falta de operadores locales } \\
\text { con conocimiento de la } \\
\text { estructuración y comercia- } \\
\text { lización de paquetes. }\end{array}$ \\
\hline & $\begin{array}{l}\text { Bajo compromiso para } \\
\text { generar políticas de soste- } \\
\text { nibilidad y responsabilidad } \\
\text { social. }\end{array}$ & $\begin{array}{l}\text { Existencia de líneas de } \\
\text { crédito para el turismo con } \\
\text { fines de mejoramiento de } \\
\text { infraestructura y dotación. }\end{array}$ & $\begin{array}{l}\text { Concentración de la ges- } \\
\text { tión gremial en ciudades } \\
\text { capitales }\end{array}$ \\
\hline
\end{tabular}

Fuente: Elaboración propia a partir de la información recogida en los planes de desarrollo turístico departamentales, 2014. 


\begin{tabular}{|c|c|c|c|}
\hline \multicolumn{4}{|c|}{ Factores de gestión } \\
\hline Fortalezas & Debilidades & Oportunidades & Amenazas \\
\hline \multirow{3}{*}{$\begin{array}{l}\text { Reconocimiento de los de- } \\
\text { partamentos y sus capita- } \\
\text { les, así como tendencia en } \\
\text { el posicionamiento de los } \\
\text { municipios y las regiones. }\end{array}$} & $\begin{array}{l}\text { Carencia de producto } \\
\text { turístico estructurado y } \\
\text { organizado con su propia } \\
\text { imagen de marca. }\end{array}$ & \multirow{3}{*}{$\begin{array}{l}\text { Aprovechamiento del foco } \\
\text { turístico capital para im- } \\
\text { pulsar el turismo regional } \\
\text { a los municipios. }\end{array}$} & $\begin{array}{l}\text { Destinos turísticos en el } \\
\text { país con atractivos simila- } \\
\text { res: gran concentración de } \\
\text { competidores. }\end{array}$ \\
\hline & $\begin{array}{l}\text { Falta de productos diver- } \\
\text { sificados que incluyan } \\
\text { el resto de atractivos del } \\
\text { departamento. }\end{array}$ & & \multirow{2}{*}{$\begin{array}{l}\text { Existe un gran interés por } \\
\text { parte de la demanda por la } \\
\text { región Caribe. }\end{array}$} \\
\hline & $\begin{array}{l}\text { Falta de innovación de } \\
\text { los productos y servicios } \\
\text { ofrecidos. }\end{array}$ & & \\
\hline \multirow{3}{*}{$\begin{array}{l}\text { Oferta comercial variada } \\
\text { por medio de los atractivos } \\
\text { naturales y culturales } \\
\text { existentes en los departa- } \\
\text { mentos. }\end{array}$} & $\begin{array}{l}\text { Poca sostenibilidad de los } \\
\text { destinos. }\end{array}$ & $\begin{array}{l}\text { Certificaciones de sosteni- } \\
\text { bilidad empresariales y de } \\
\text { los destinos. }\end{array}$ & $\begin{array}{l}\text { No se logra la consoli- } \\
\text { dación de alianzas con } \\
\text { mayoristas para la oferta } \\
\text { regional. }\end{array}$ \\
\hline & $\begin{array}{l}\text { Falta de mecanismos para } \\
\text { informar y orientar al turis- } \\
\text { ta en los destinos. }\end{array}$ & $\begin{array}{l}\text { Complementariedad de las } \\
\text { ofertas capitalinas con la } \\
\text { subregional para el diseño } \\
\text { de planes alternativos. }\end{array}$ & $\begin{array}{l}\text { Desconocimiento de la } \\
\text { oferta turística subregional } \\
\text { por parte de la demanda. }\end{array}$ \\
\hline & $\begin{array}{l}\text { Falta de empaquetamiento } \\
\text { de los destinos. }\end{array}$ & $\begin{array}{l}\text { Paquetes multidestino, in- } \\
\text { cluso entre departamentos. }\end{array}$ & $\begin{array}{l}\text { Falta de consolidación de } \\
\text { productos comunitarios } \\
\text { por la carencia de produc- } \\
\text { tos estructurados, planta } \\
\text { turística no apta y falta de } \\
\text { preparación por parte de } \\
\text { las comunidades. }\end{array}$ \\
\hline \multirow{2}{*}{$\begin{array}{l}\text { Existencia de sitios reco- } \\
\text { nocidos como patrimonio } \\
\text { mundial de la humanidad } \\
\text { por la UNESCO: Centro } \\
\text { Histórico de Cartagena, } \\
\text { Carnaval de Negros y } \\
\text { Blancos, Paisaje Cultural } \\
\text { Cafetero (PCC). }\end{array}$} & \multirow{2}{*}{$\begin{array}{l}\text { Algunos destinos turísticos } \\
\text { nacionales muy recono- } \\
\text { cidos opacan al resto, por } \\
\text { ejemplo, Cartagena. }\end{array}$} & $\begin{array}{l}\text { Mayor demanda de sitios } \\
\text { turísticos reconocidos por } \\
\text { la UNESCO. }\end{array}$ & \\
\hline & & $\begin{array}{l}\text { Utilizar el reconocimiento } \\
\text { de estos atractivos para } \\
\text { posicionar su oferta com- } \\
\text { plementaria y cercana. }\end{array}$ & \\
\hline \multirow{3}{*}{$\begin{array}{l}\text { Material gráfico de calidad } \\
\text { como soporte y promoción } \\
\text { de la actividad turística. }\end{array}$} & $\begin{array}{l}\text { Material promocional no } \\
\text { disponible fácilmente para } \\
\text { el turista. }\end{array}$ & \multirow{3}{*}{$\begin{array}{l}\text { Fortalecimiento de la } \\
\text { política de promoción tu- } \\
\text { rística internacional en los } \\
\text { últimos años. }\end{array}$} & \\
\hline & $\begin{array}{l}\text { Falta de promoción y co- } \\
\text { mercialización turística de } \\
\text { los destinos. }\end{array}$ & & \\
\hline & $\begin{array}{l}\text { Baja visibilidad de infor- } \\
\text { mación turística en los } \\
\text { sitios web y en redes socia- } \\
\text { les institucionales. }\end{array}$ & & \\
\hline \multirow{2}{*}{$\begin{array}{l}\text { Buen posicionamiento de } \\
\text { los destinos turísticos de- } \\
\text { partamentales en la mente } \\
\text { de los turistas. }\end{array}$} & $\begin{array}{l}\text { Falta de planes de merca- } \\
\text { deo y promoción. }\end{array}$ & \multirow{2}{*}{$\begin{array}{l}\text { Algunos destinos turísticos } \\
\text { comienzan a despertar } \\
\text { un interés que antes no } \\
\text { despertaban, por ejemplo, } \\
\text { Mompox, La Guajira, etc. }\end{array}$} & \multirow{2}{*}{$\begin{array}{l}\text { Mala imagen asociada } \\
\text { a problemas de orden } \\
\text { público. }\end{array}$} \\
\hline & $\begin{array}{l}\text { Débil investigación de } \\
\text { mercados y estudios que } \\
\text { caractericen la demanda. }\end{array}$ & & \\
\hline
\end{tabular}




\begin{tabular}{|c|c|c|c|}
\hline \multicolumn{4}{|c|}{ Factores de gestión } \\
\hline Fortalezas & Debilidades & Oportunidades & Amenazas \\
\hline \multirow{2}{*}{$\begin{array}{l}\text { Presencia de atractivos y } \\
\text { actividades en guías nacio- } \\
\text { nales e internacionales. }\end{array}$} & \multirow{2}{*}{$\begin{array}{l}\text { No hay aplicación ni cum- } \\
\text { plimiento de las políticas } \\
\text { de restauración y manteni- } \\
\text { miento de BIC, CH, etc. }\end{array}$} & \multirow{2}{*}{$\begin{array}{l}\text { Incremento de la demanda } \\
\text { de turismo de naturaleza y } \\
\text { actividades relacionadas, } \\
\text { además del auge del turis- } \\
\text { mo cultural, ecoturismo, } \\
\text { etnoturismo, agroturismo, } \\
\text { turismo de golf, turismo } \\
\text { arqueológico, etc. }\end{array}$} & Peligro de masificación. \\
\hline & & & $\begin{array}{l}\text { Aculturación de la comu- } \\
\text { nidad receptora. }\end{array}$ \\
\hline \multirow{3}{*}{$\begin{array}{l}\text { Presencia de entidades que } \\
\text { aportan a la gestión y al } \\
\text { desarrollo de la actividad } \\
\text { turística. }\end{array}$} & $\begin{array}{l}\text { Débiles procesos de plani- } \\
\text { ficación. }\end{array}$ & $\begin{array}{l}\text { Existencia de una base } \\
\text { normativa en el ámbito } \\
\text { nacional, la cual regula la } \\
\text { actividad turística. }\end{array}$ & \\
\hline & Frágil institucionalidad. & $\begin{array}{l}\text { Existencia de políticas sec- } \\
\text { toriales y de lineamientos } \\
\text { estratégicos en el ámbito } \\
\text { nacional, que orientan la } \\
\text { actividad turística. }\end{array}$ & \\
\hline & $\begin{array}{l}\text { Débil participación de la co- } \\
\text { munidad local en decisiones } \\
\text { estratégicas de desarrollo y } \\
\text { gestión de los destinos. }\end{array}$ & $\begin{array}{l}\text { Existencia de recursos del } \\
\text { Fondo Nacional de Promo- } \\
\text { ción Turística. }\end{array}$ & \\
\hline \multirow[t]{2}{*}{$\begin{array}{l}\text { Presencia de gremios } \\
\text { turísticos, sobre todo en } \\
\text { las ciudades capitales de } \\
\text { departamentos. }\end{array}$} & $\begin{array}{l}\text { Falta de presencia de } \\
\text { gremios turísticos en las } \\
\text { zonas rurales o cabeceras } \\
\text { municipales. }\end{array}$ & & \\
\hline & Falta de asociatividad. & & \\
\hline $\begin{array}{l}\text { Tendencia a la gestión } \\
\text { turística mediante comités } \\
\text { de turismo, corporaciones } \\
\text { mixtas, mesas de planifica- } \\
\text { ción y trabajo en equipo. }\end{array}$ & & $\begin{array}{l}\text { Creación de clubes de } \\
\text { producto acordes con la } \\
\text { vocación del destino y la } \\
\text { madurez del producto. }\end{array}$ & \\
\hline $\begin{array}{l}\text { Participación en ferias y } \\
\text { eventos turísticos tanto } \\
\text { nacionales como interna- } \\
\text { cionales. }\end{array}$ & $\begin{array}{l}\text { Poco impulso al turismo } \\
\text { local. La atención se centra } \\
\text { en el turismo extranjero. }\end{array}$ & $\begin{array}{l}\text { Posicionar productos } \\
\text { especializados en ferias y } \\
\text { eventos especializados pa- } \\
\text { ra nichos muy concretos. }\end{array}$ & \\
\hline \multirow{2}{*}{$\begin{array}{l}\text { Existencia de marca terri- } \\
\text { torial (departamental) o } \\
\text { marca ciudad. }\end{array}$} & $\begin{array}{l}\text { Poca difusión de las mar- } \\
\text { cas territoriales. }\end{array}$ & & \\
\hline & $\begin{array}{l}\text { No existe adopción de } \\
\text { estas por parte del sector } \\
\text { empresarial. }\end{array}$ & & \\
\hline & & $\begin{array}{l}\text { Pocas restricciones mi- } \\
\text { gratorias de turistas extran- } \\
\text { jeros en Colombia. }\end{array}$ & \\
\hline & & $\begin{array}{l}\text { Existencia de socios co- } \\
\text { merciales del área andina } \\
\text { (Venezuela, Ecuador, Perú, } \\
\text { etc.) que podrían reportar } \\
\text { importantes flujos de visi- } \\
\text { tantes internacionales. }\end{array}$ & \\
\hline
\end{tabular}

Fuente: Elaboración propia a partir de la información recogida en los planes de desarrollo turístico departamentales, 2014. 


\section{Anexo 7. Concentración de atractivos turísticos en los departamentos}

\section{Departamento de Cundinamarca}

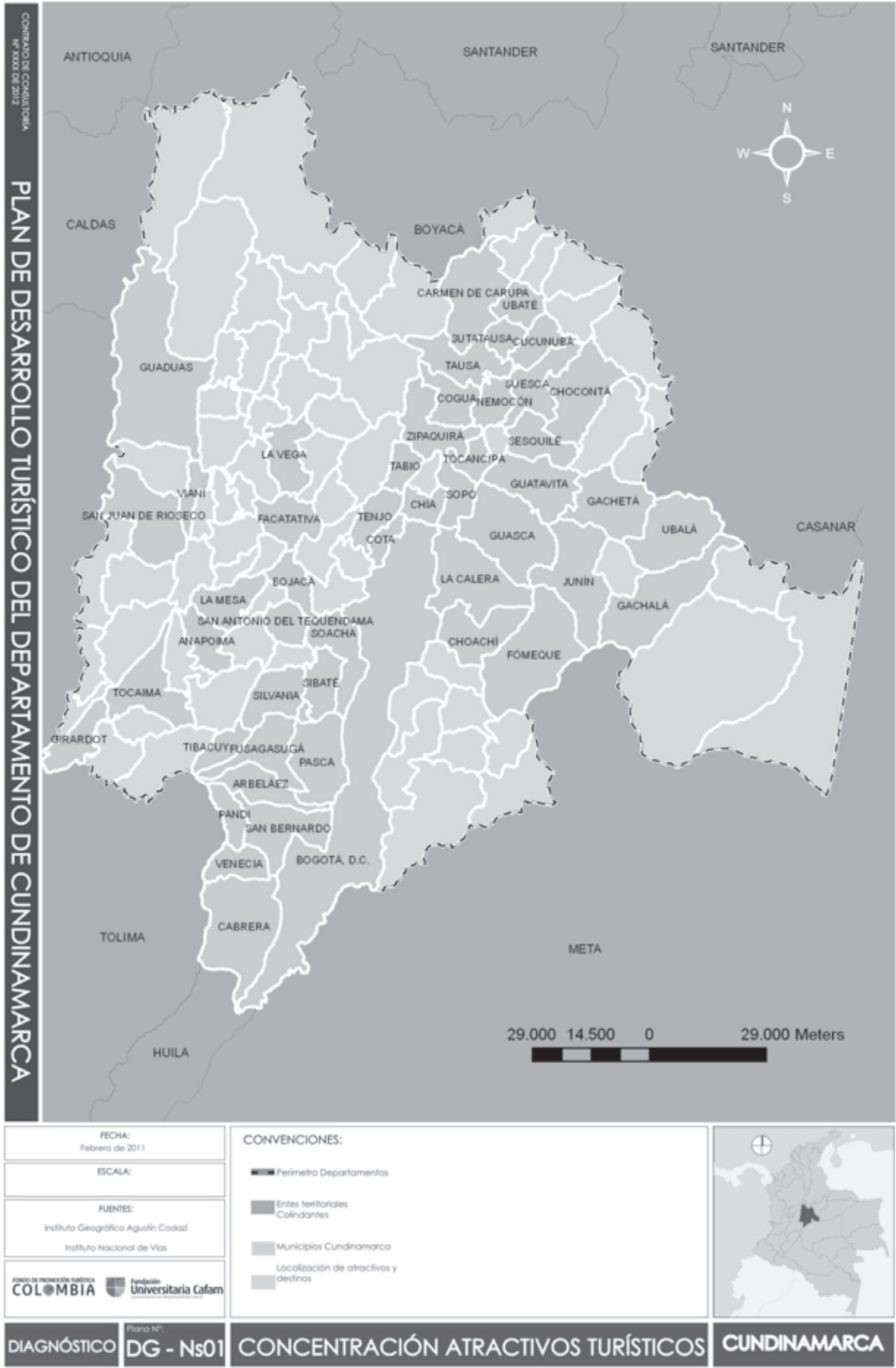

Fuente: Unión Temporal de Turismo, 2012. 


\section{Departamento de La Guajira}

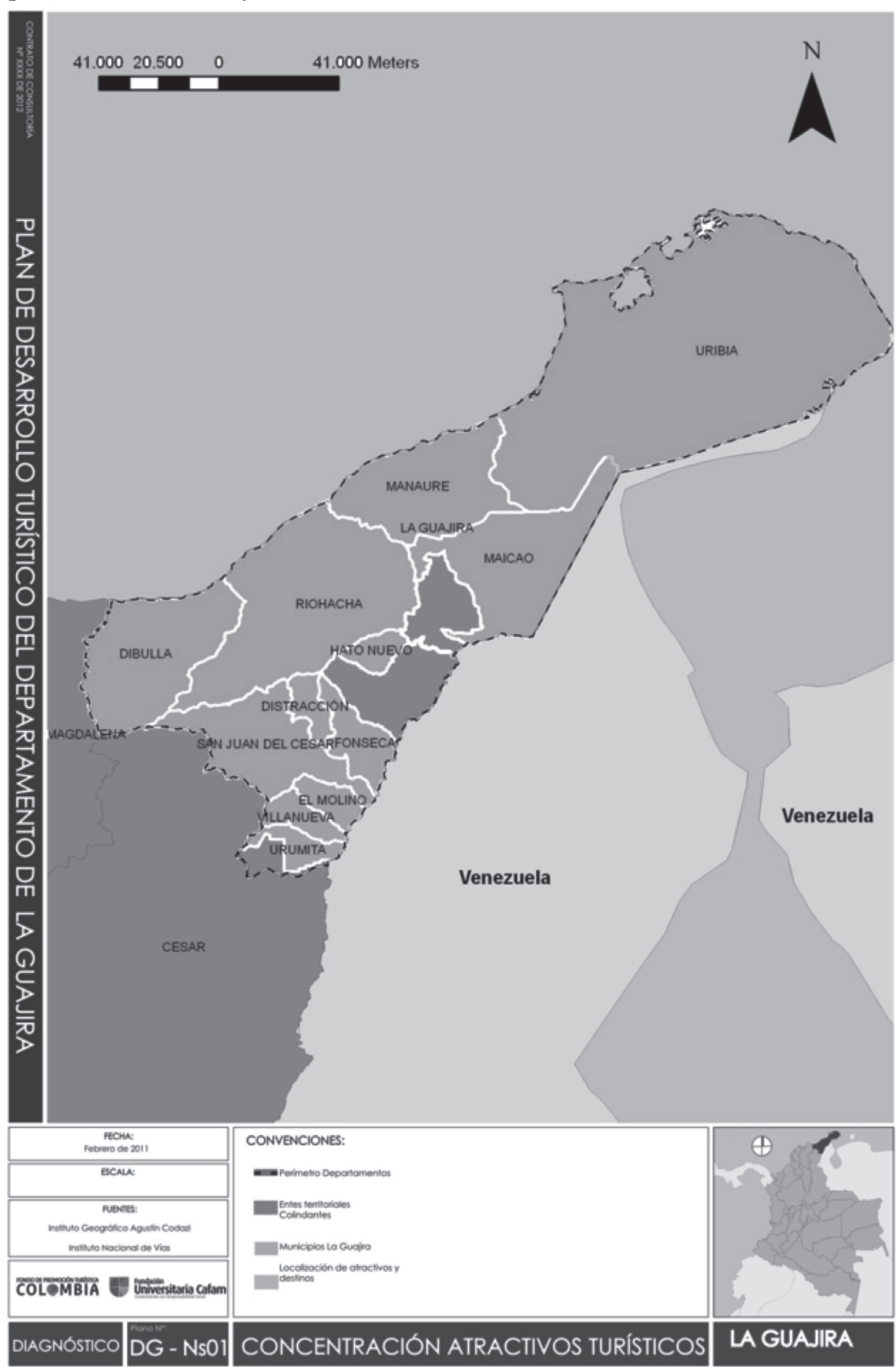

Fuente: Unión Temporal de Turismo, 2012. 


\section{Departamento de Santander}

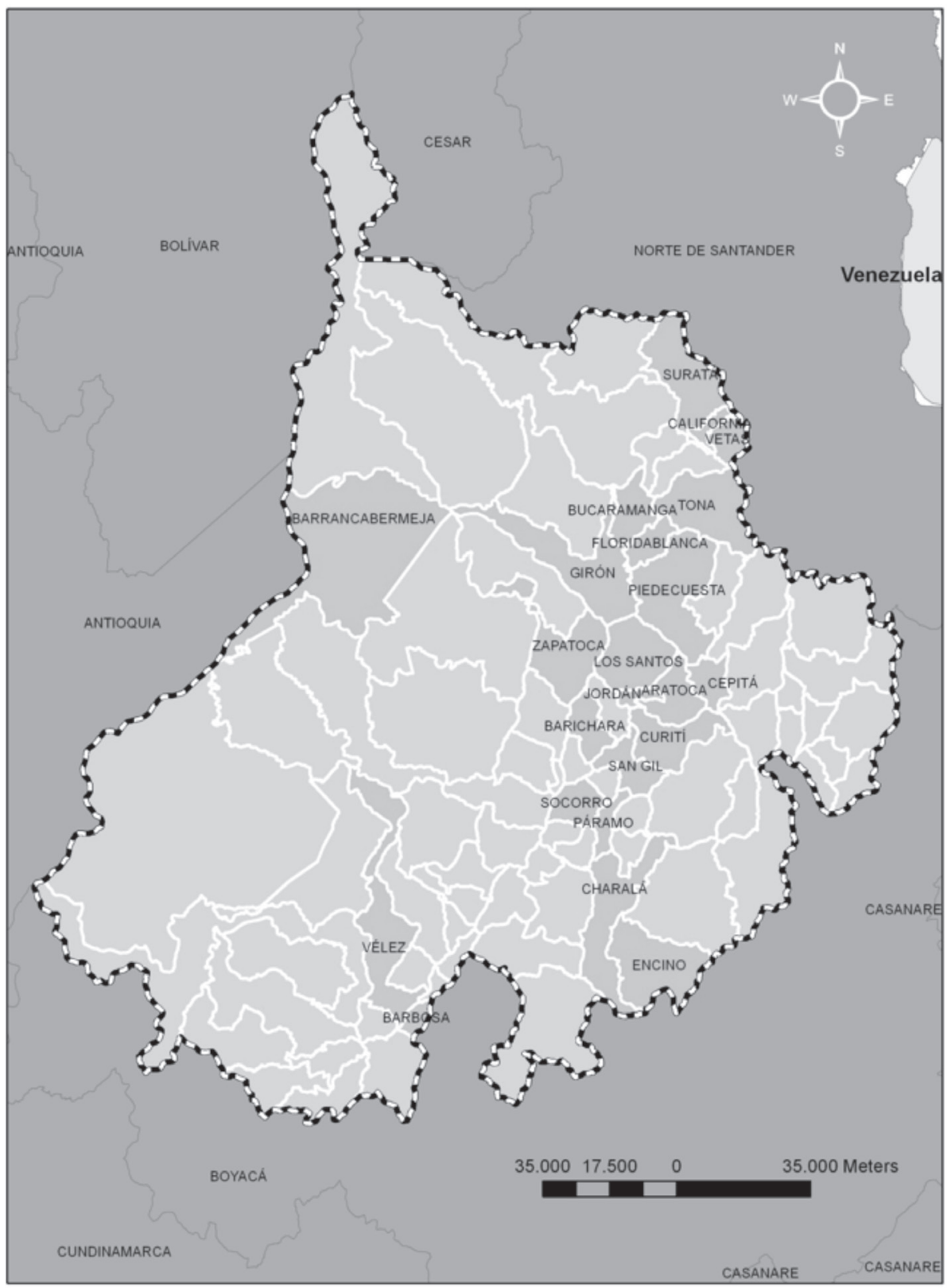

Fuente: Unión Temporal de Turismo, 2012. 


\section{Departamento de Norte de Santander}

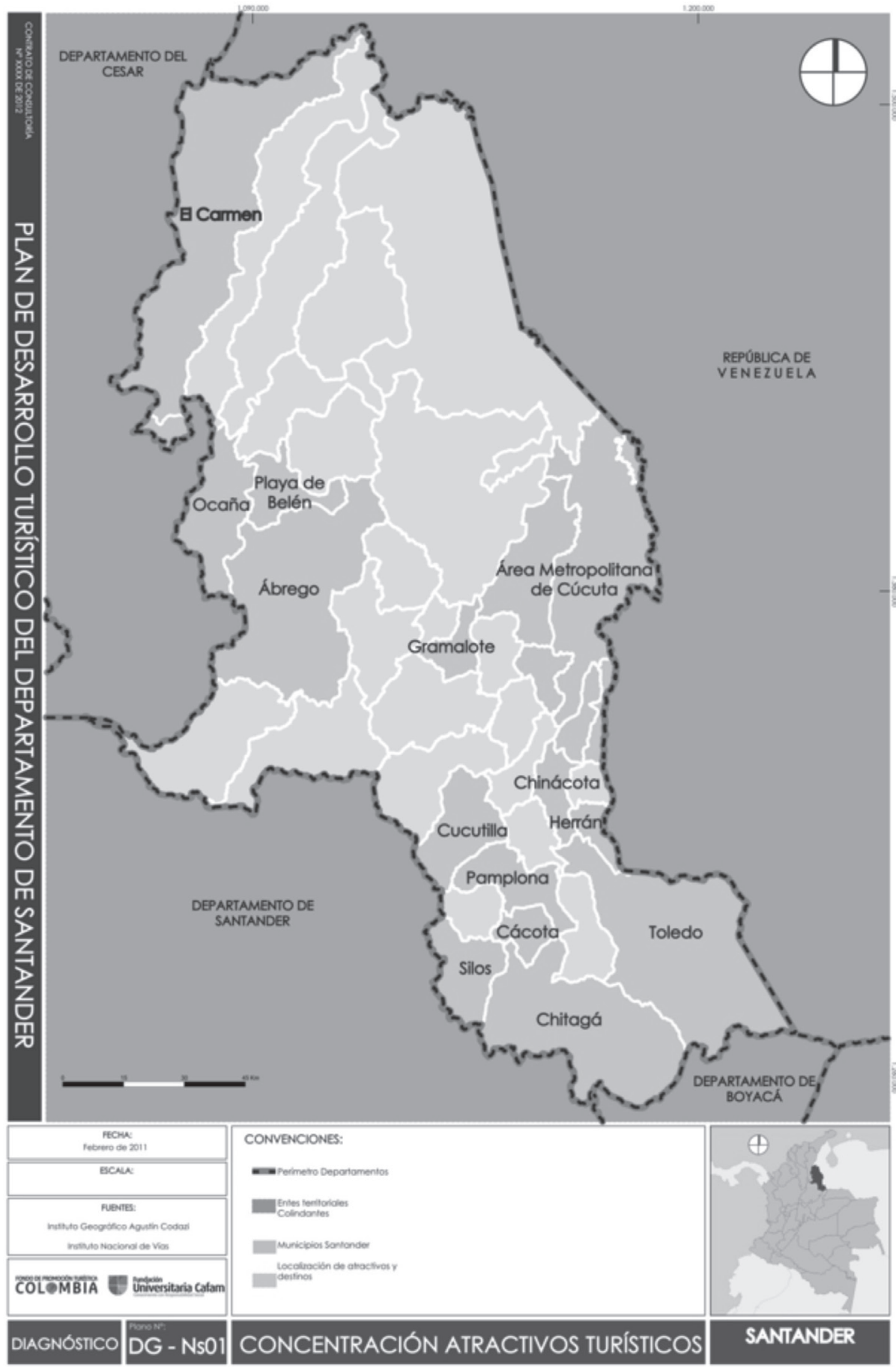

Fuente: Unión Temporal de Turismo, 2012. 


\section{Departamento de Antioquia}

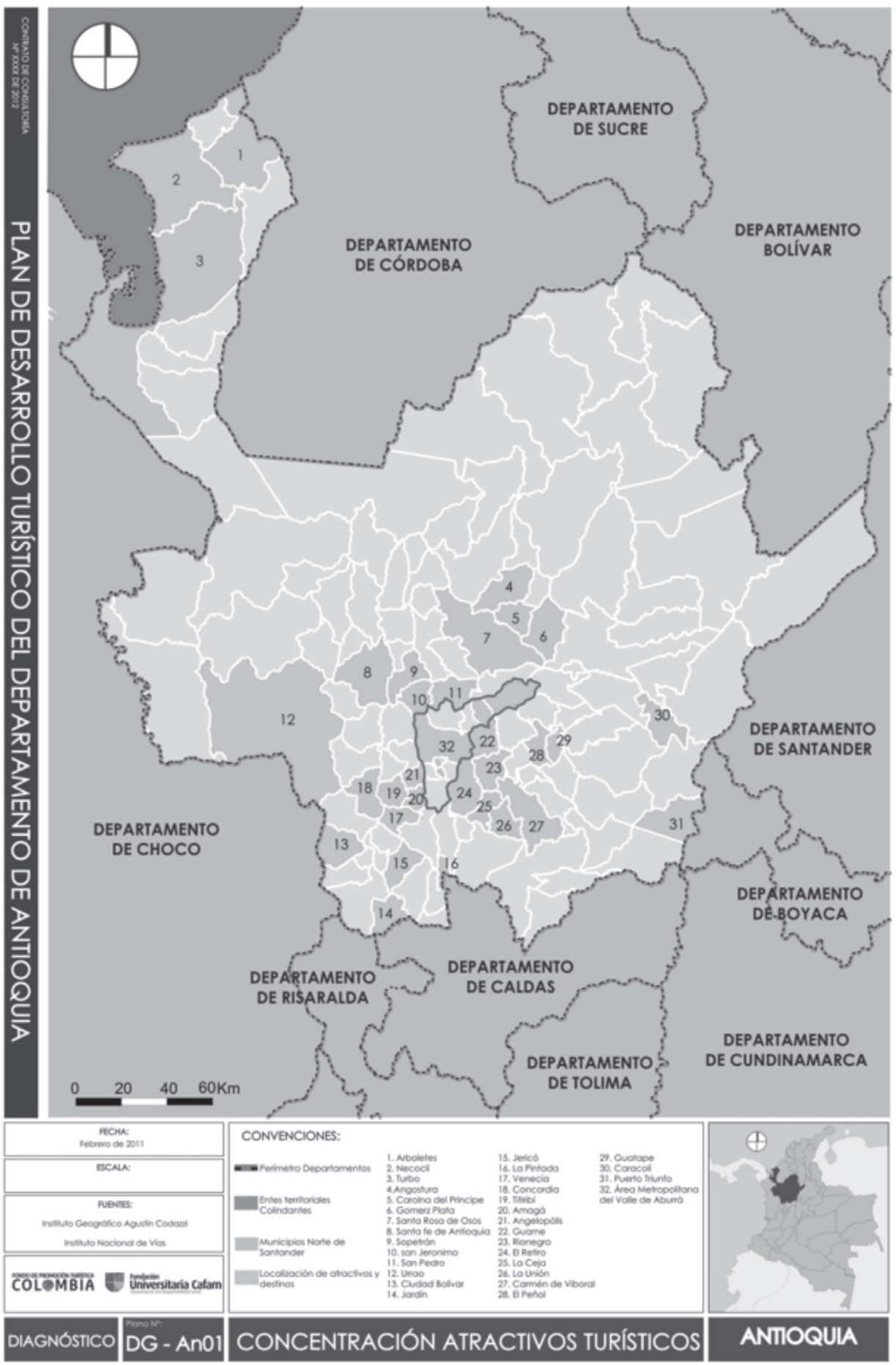

Fuente: Unión Temporal de Turismo, 2012. 


\section{Departamento de Valle del Cauca}

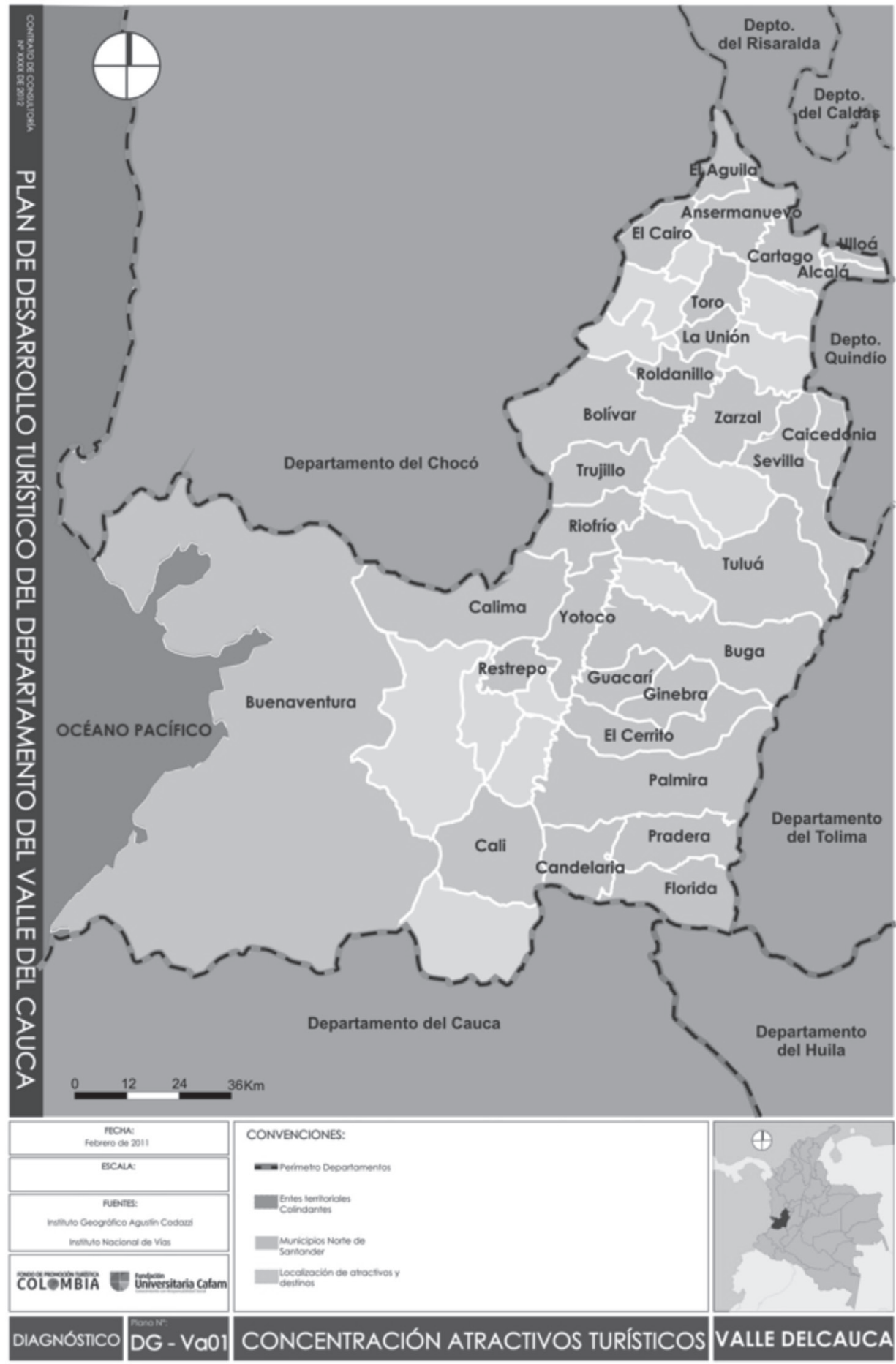

Fuente: Unión Temporal de Turismo, 2012. 